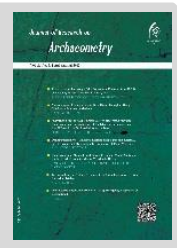

\title{
A Micromorphological Analysis of the Neolithic Site of Mahtaj, Behbahan Plain
}

\author{
Elham Fotuhi Dilanchi ${ }^{1}$, Hojjat Darabi ${ }^{2 \star}$, Saman Heydari Guran ${ }^{3}$ \\ ${ }^{1}$ M.A in Archaeology, Razi University, Kermanshah, IRAN \\ ${ }^{2}$ Assistant Professor of Archaeology, Razi University, Kermanshah, IRAN \\ ${ }^{3}$ Neanderthal Museum, Germany and Diyarmehr Institute for Palaeolithic Research, IRAN, IRAN
}

Received: 31/01/2020

Accepted: $14 / 06 / 2020$

\begin{abstract}
One of the long-lasting discussions concerning early Neolithic sites in the Iranian plateau deals with the issue of seasonal or permanent settlements that is directly related to level of human mobility during this period. It is noteworthy that this time period coincided with earliest signs of sedentary life style and domestication of some species of animal and plants. What kinds of activities were usually focused by the early Neolithic societies? In addition to the normal archaeological finds, understanding the site formation processes -as a new approach- and the kinds of on-site human activities are also increasingly of importance. Most importantly, micromorphological analysis is playing an increasing role in this case. Therefore, to better understand the nature of deposition and sorts of various activities that might have been done in the past, the Late PPN site of Tapeh Mahtaj was examined. The site is located on a natural hillock composed of fine and fertile sediments of the Behbahan plain, south-western Iran, close to the foothill of the Zagros Mountains. The site was briefly excavated in 2015 and as a result, stratigraphic observations attested to the presence of three major occupational phases. However, further information left with analysis of a micromorphological sample that was taken from the north trench-section of the site, where it provided a maximum amount of its deposits. The results of site formations analyses by thin section studies at Tapeh Mahtaj identified several occupational phases as a sequence of human activities. This study revealed living floors that are shown by plastering, infillings, numerous charcoal and bone fragments, face pigments, organic materials and exciting mineral elements such as phosphate. All these findings present the nature of human activities in the Mahtaj site during the time spanning from late 8 th to early 7 th Millennium BC. It should be noted that this chronological time frame of the site has also recently been suggested by radio-carbon dating, where this time period is archaeologically consisted with the emergence of the initial ceramics across the Near East. This highlights the key role of such micromorphological analyses to track those activities associated with early pottery making. At a site-level, however, one of the most interesting results of the micromorphological analysis is the discovery of a dung pellet in the lowest stage of the site occupation. This shows that the site occupants might have dealt with animal husbandry, presumably goat herding. It is also believed that the site was probably used as seasonal campsite for mobile pastoralists during the late 8th millennium BC. Additionally, the observation through thin sections such as bioturbations, temperature fluctuations effects (clay cracks), and twist flow in deposits by freeze/thaw, diffused iron oxide nodules indicate a short-term seasonal use of the site during the cool, wet periods. Overall, the site formation study at Mahtaj matches with the archaeological evidence such as the low density of archaeological finds and the low volume as well
\end{abstract}

*Corresponding author: hojjatdarabi@gmail.com

Copyright $₫$ 2020, the Authors / This open-access article is published under the terms of the Creative Commons Attribution-NonCommercial 4.0 International License which permits Share (copy and redistribute the material in any medium or format) and Adapt (remix, transform, and build upon the material) under the Attribution-

NonCommercial .terms 
Fotuhi Dilanchi, E et al. / Journal of Research on Archaeometry 1 (2020) 81-96

as nature of the deposits remained. These all point to the presence and mechanism of the early occupants of the Behbehan Plain who had intensive interactions with the nearby highland Zagros Mountains.

Keywords: Pre-pottery Neolithic, Iranian Plateau, Behbahan Plain, Micromorphology, Tapeh Mahtaj, Early Animal Herding 


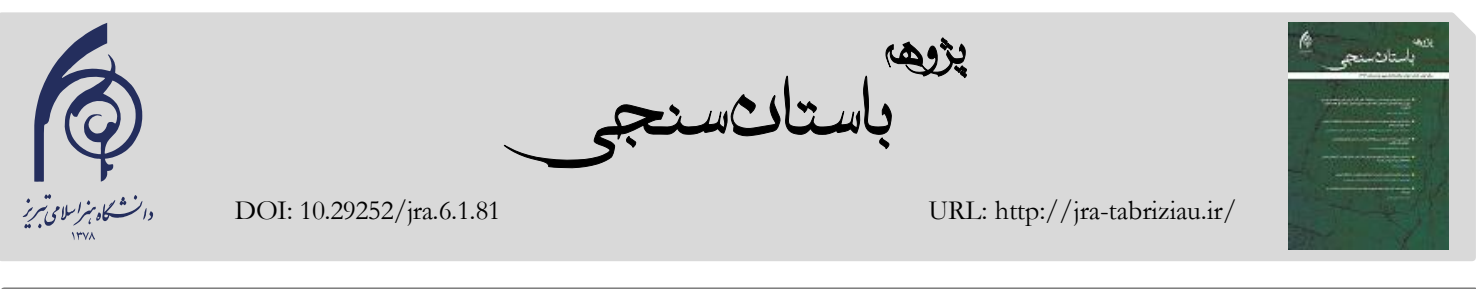

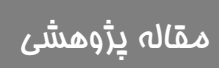

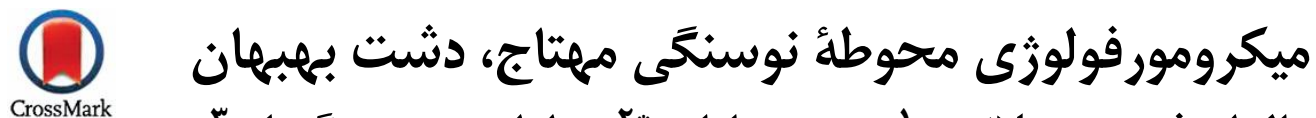

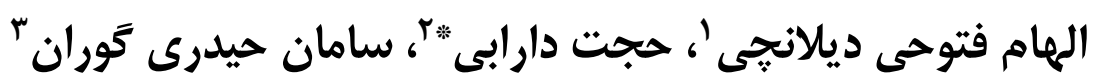

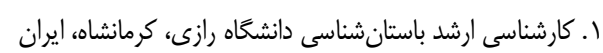

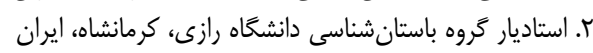

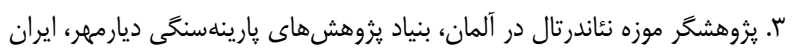

تاريخ بِذيرش:

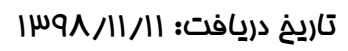

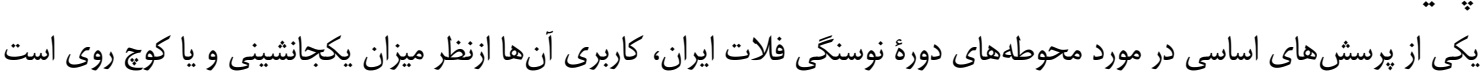

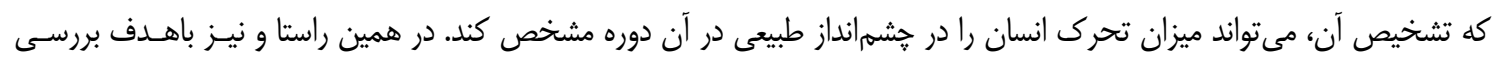

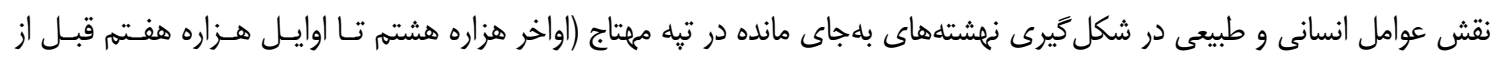

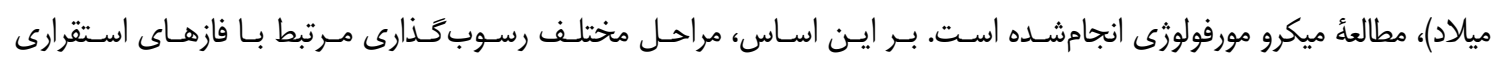

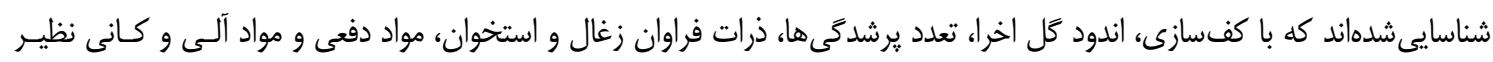

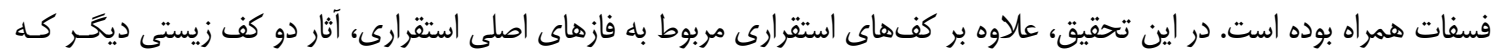

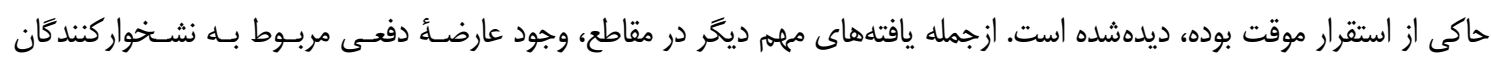

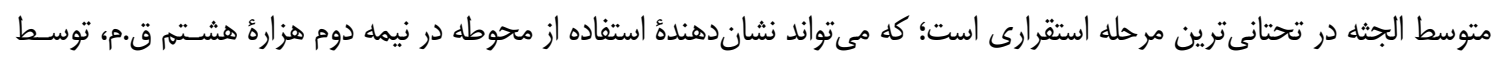

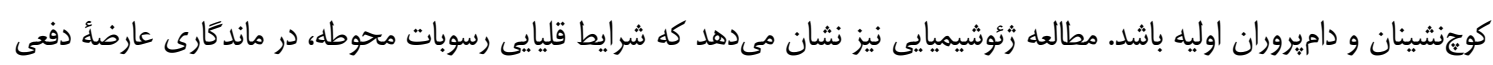

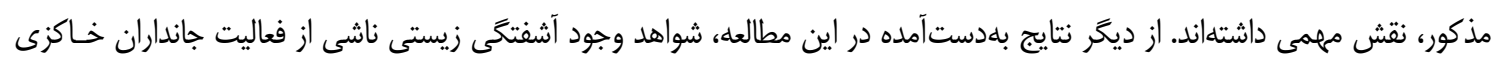

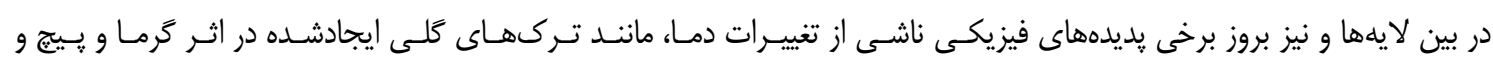

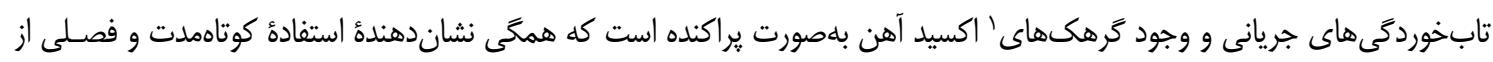

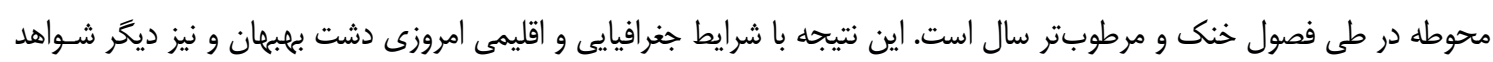

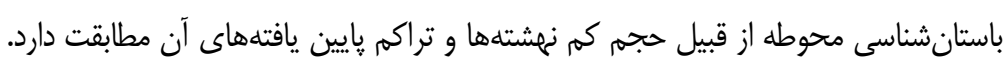

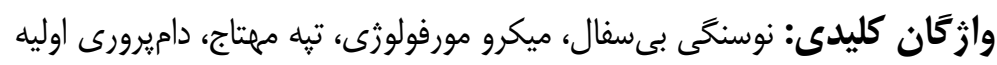

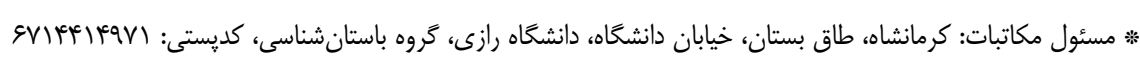

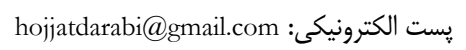
C) حق نشر متعلق به نويسنده(كان) است و نويسنده تحت مجوز Creative Commons Attribution License به مجله اجازه مى دهد مقاله خاب شده را با ديخران به اشتراك بكذارد منوط بر اينكه حقوق مؤلف اثر حفظ و به انتشار اوليه مقاله در اين مجله اشاره شود. 
توجـهـ بــهـ ايــن مقدمـه، از همــين روش بــراى مطالعـهـ نهشتههاى تبه مهتاج در شهرستان بهببهان استفادهشده تا

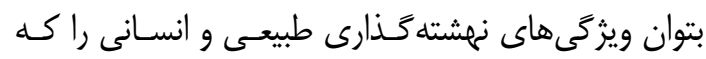

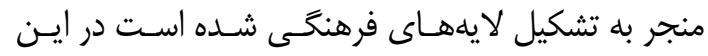

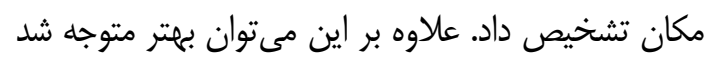

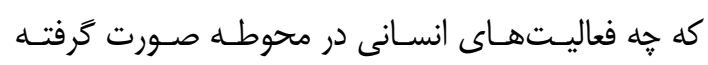

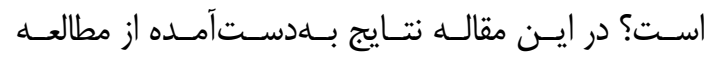

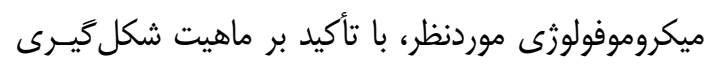

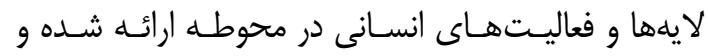

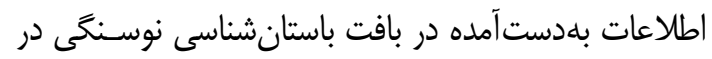
منطقه موردبحث قرار خواهد كرفت.

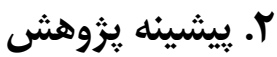

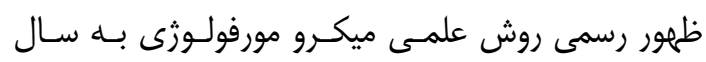

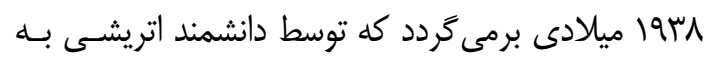

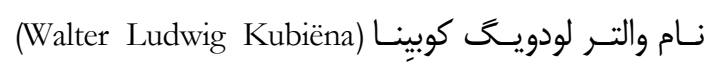
مطرح شد. وى به دليل تهيئ مقاطع نازى خـاك و ايجـاد

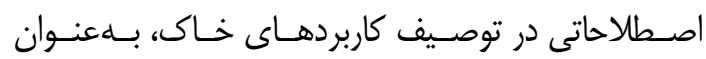

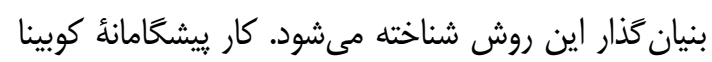

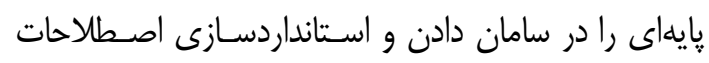
توصيفى براى تفسير و طبقهبندى خـاك، فـراهم آورد [6].

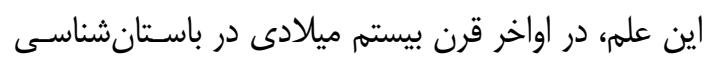

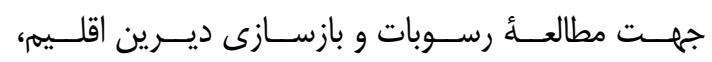

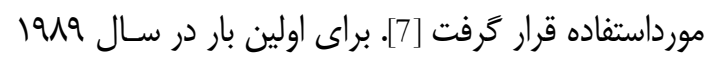

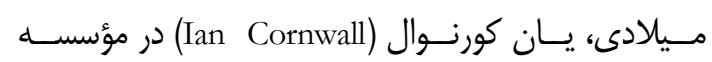

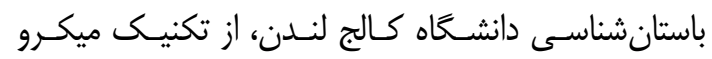

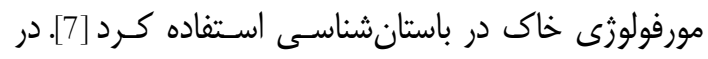

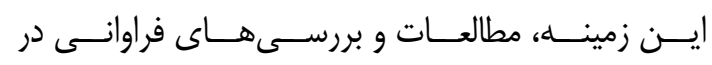

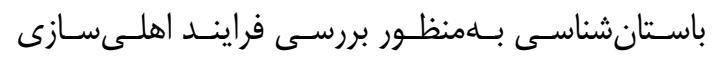

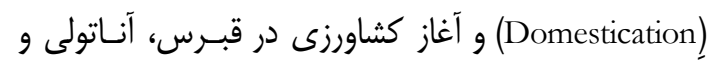

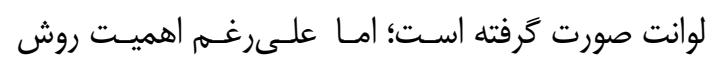
ميكرو مورفولوزى در مطالعات باستانشناسى، تاكنون ايـن إنـ

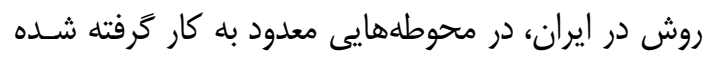

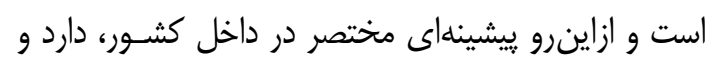

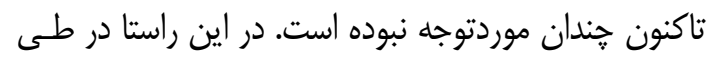

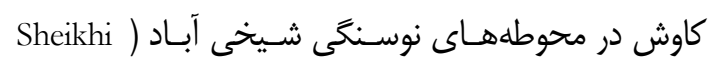

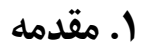

يكى از مسائل كليدى در باستانشناسى، تشخيص محل و

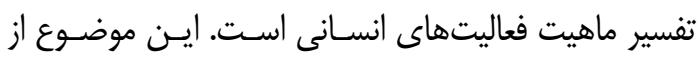
حيث تحليل مكانى (Spatial Analysis) اهميت زيادى دارد [1]. از ســـوى ديخــر، عوامــل غير انسـانى و طبيعـى در شكل گيرى نهشتهها در محوطهها نيز نقش مهمى دارند و واني

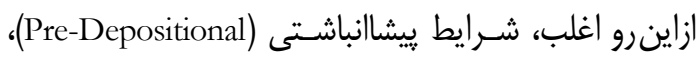

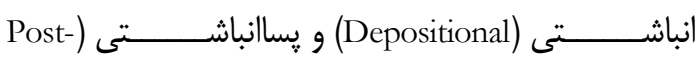

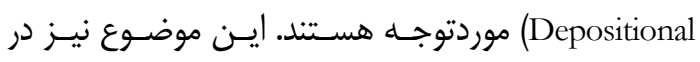
بررسى شكل گيـرى محوطــهـ (Site Formation)، جايخـاه بالايى دارد [2]. رسوباتى كه تأثير محـيط بـر مكـانهـائ

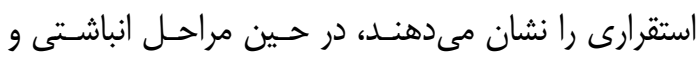

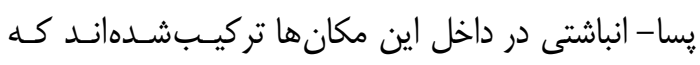

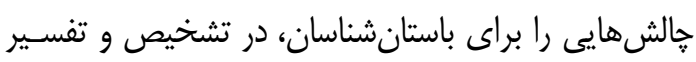

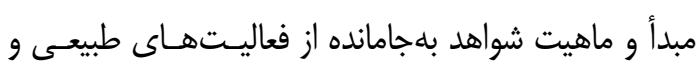

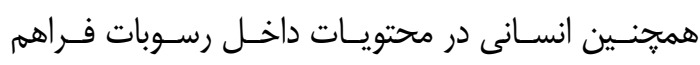

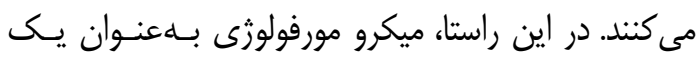

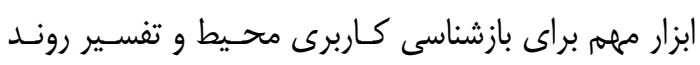

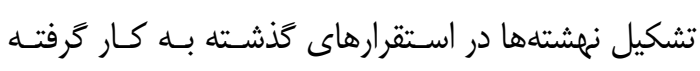

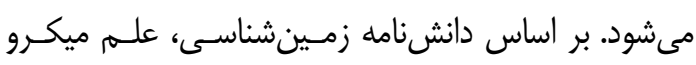

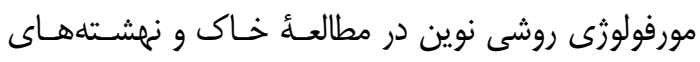
طبيعى و باستانى محسوب مى فود و در طى آن با با استفاده

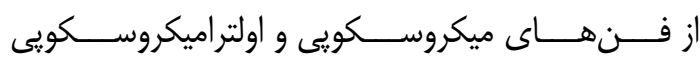

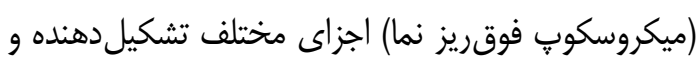

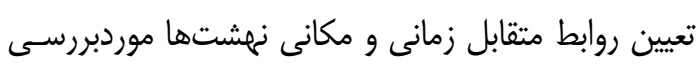

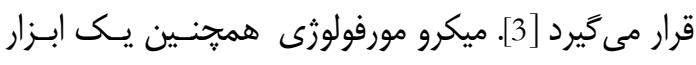

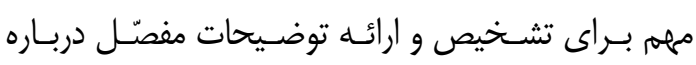

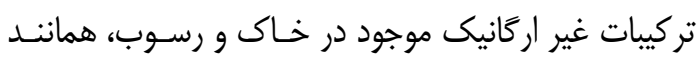

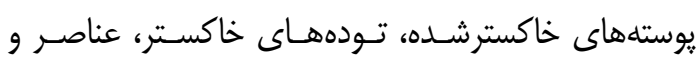

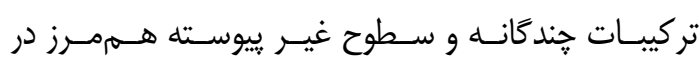

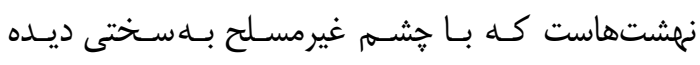

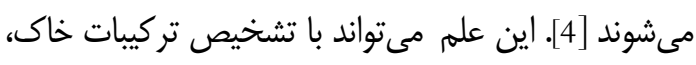

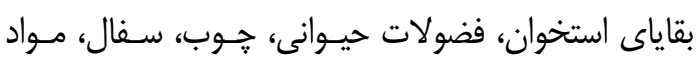

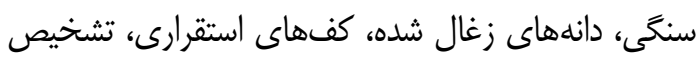

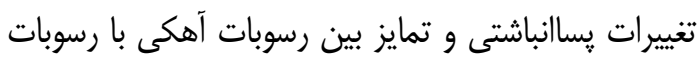
كلسيه كربنات ثانويه به باستان شناسى كمك كند [5]. بـا

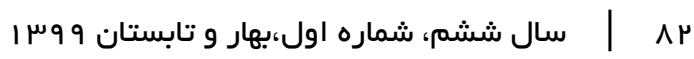


كر هكها، به دست أوردند. حضـور خـاك ريزدانسه جهـت كشاورزى و سفالسـازى، تـأثير بسـيار زيـادى در مكـان

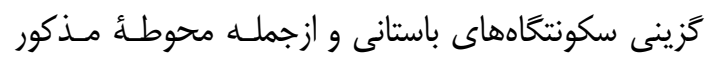

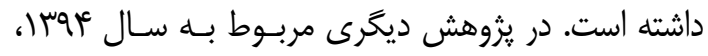

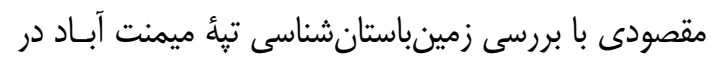

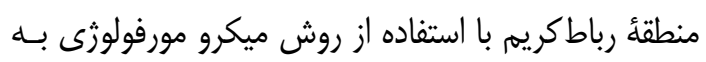
نتايجى دست يافت كه نشان مى داد قبل از شروع اسـتقرار

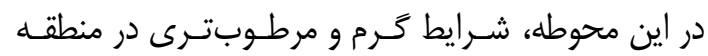

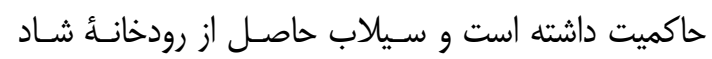
جاى نقش مهمى در از بين رفـتن اسـتقرار در آن، داشـته

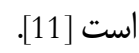

\section{". معرفى محوطة مور دمطالعه}

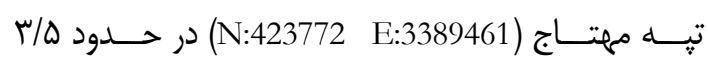

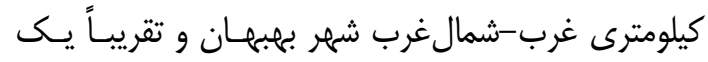

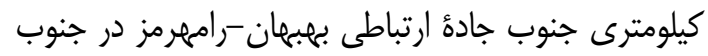

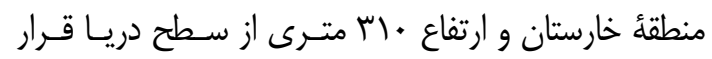

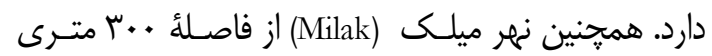

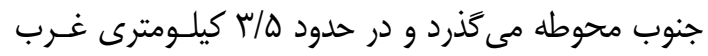

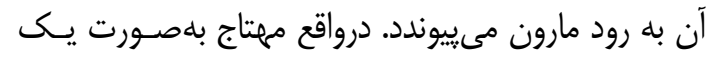

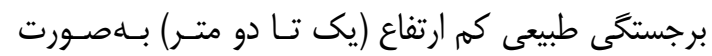

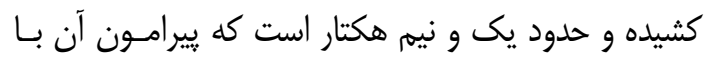
كانال هاى آبيارى احاطهشده است. سطح محوطه تسـطيح

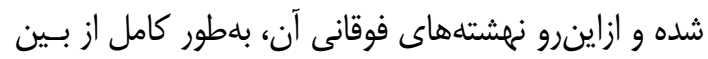

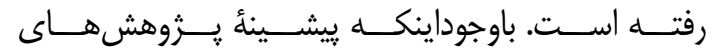

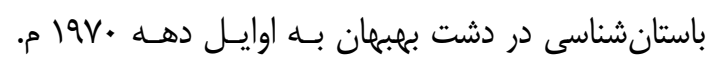
برمى گردد، تبه مهتاج صرفاً براى اولين بار در بررسى سال

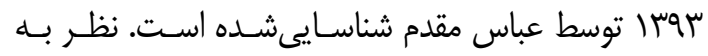

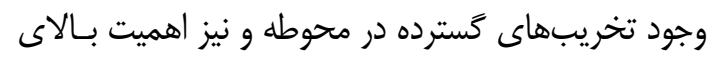

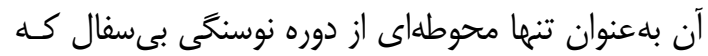

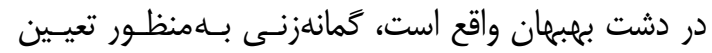

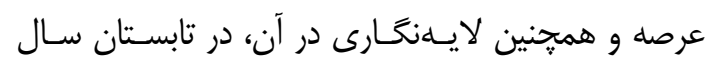

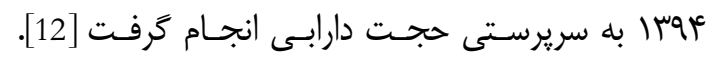

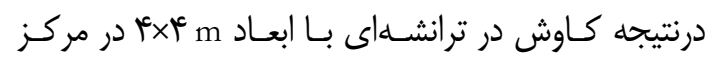

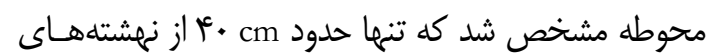
تحتانى در تبه مهتاج بلهجـاى مانـــه اسـت كـه ســـ فـاز

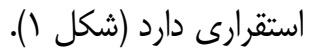
$\Lambda \mu$ سال ششم، شماره اول،بهار و تابستان 9 وس 1 و
(Abad و جانى (Jani) در استان كرمانشـاه توسـط هيئست

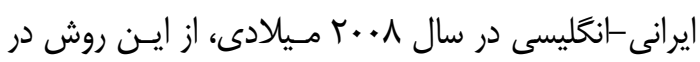

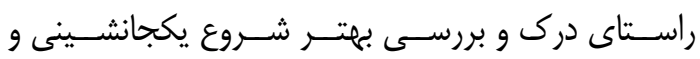
اهلى سازى استفاده شد. درنتيجأ مطالعـات ونـــى متيـوز

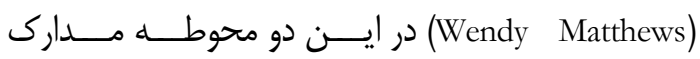

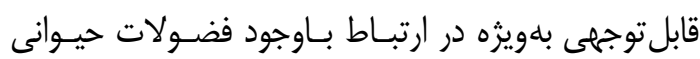

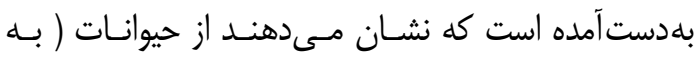

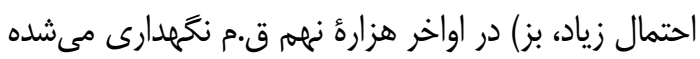

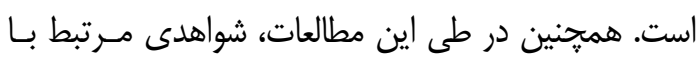

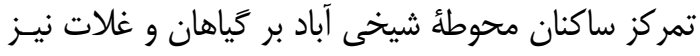
بلهدست آمده است [8]. ازجمله مطالعات ميكرو مورفولـوزى مانى

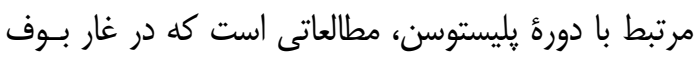

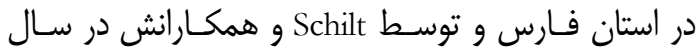

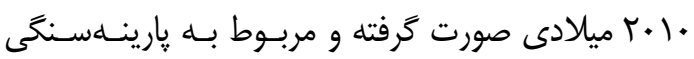
نوين است. در يك و نيم متر، رسوبات كاوش شده در اين

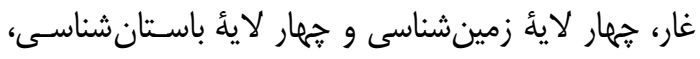

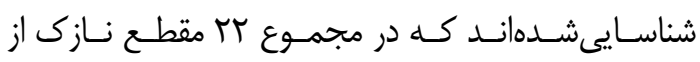
لايههاى باستانى آن، تهيه شده است. يكى آنس داز نتايج ميكرو

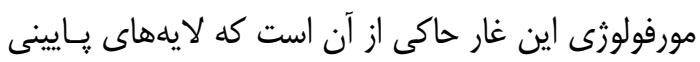

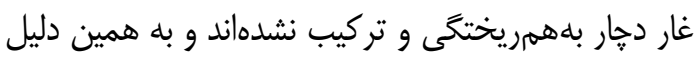

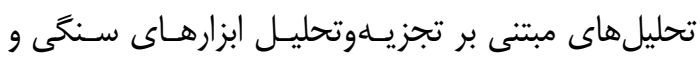

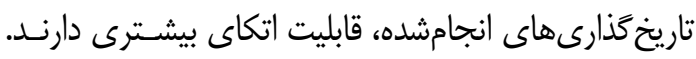

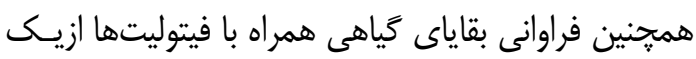
سو و از سوى ديخر وقوع اسفروليت كلسـيت ( Spherolite

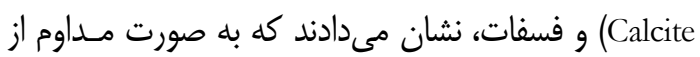

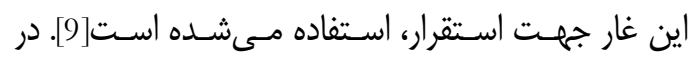
يزوهشى كه توسط مقصودى در سـال سوسا انجـامشـده

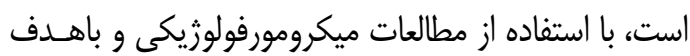

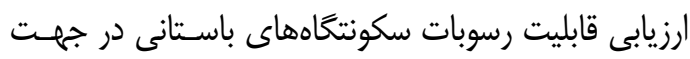

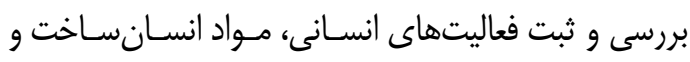

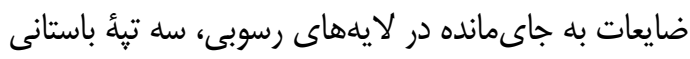

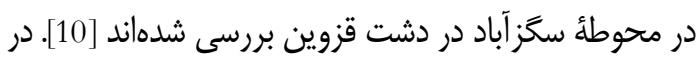

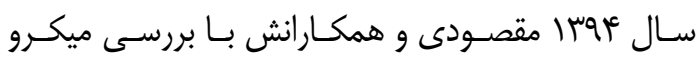

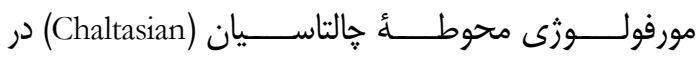

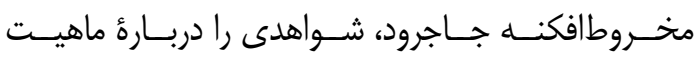

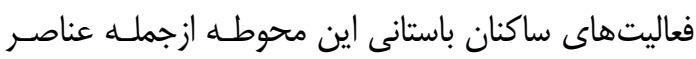

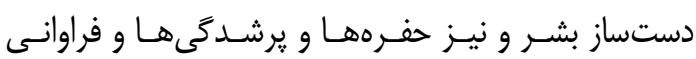




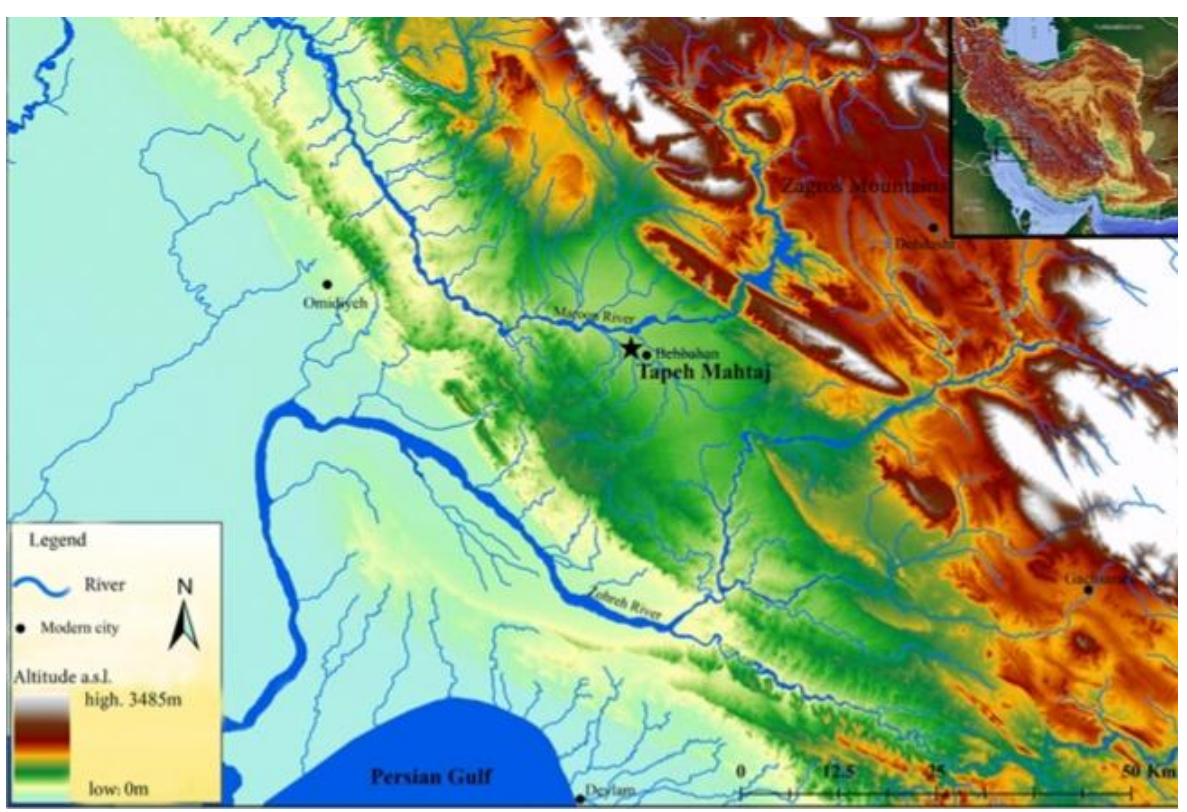

شكل (: موقعيت محوطه تِّه مهتاج در دشت بهبهان (Darabi et al. 2017) (N:423772 E:3389461)

Fig.1: Map shows Behbahan Plain and the location of Tapeh Mahtaj, (N: 423772 E: 3389461),(Darabi et al. 2017)

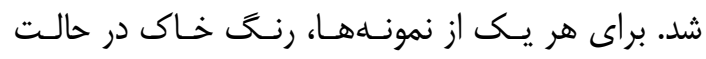
خشك، بر اساس جدول مانسل ثبت شـــ رنــ نمونسأ

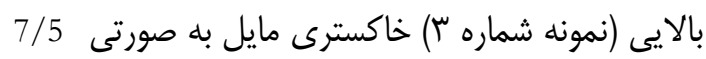

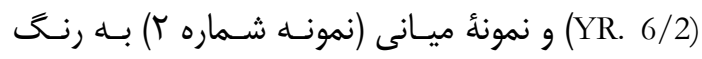

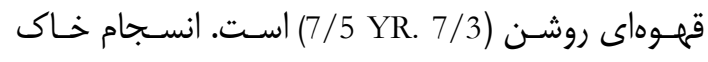

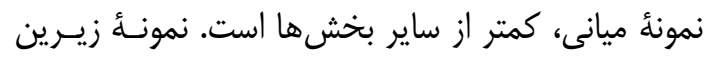

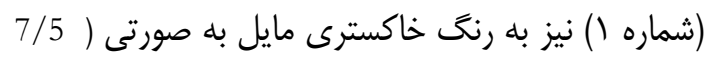

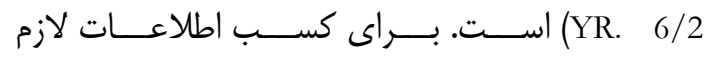

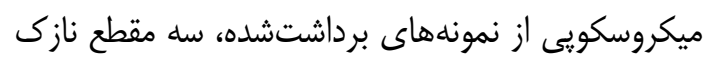

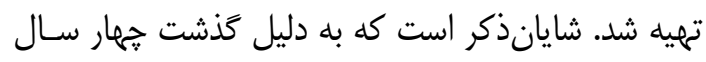

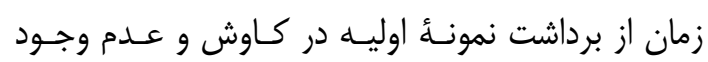

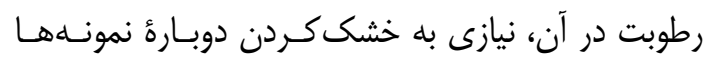

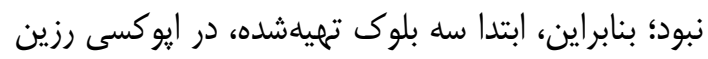

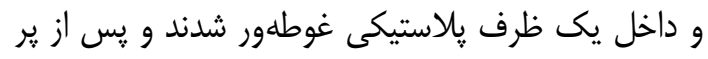

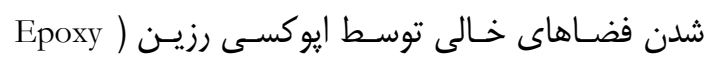

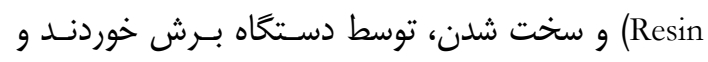

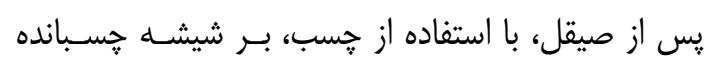

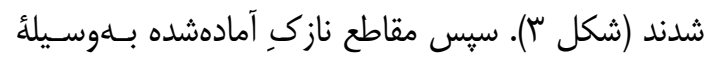

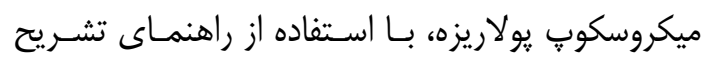

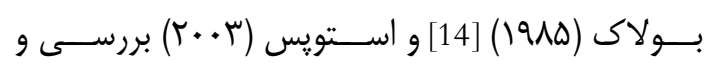
توصيف شدند.

\section{ع. مواد مطالعاتى و روشها}

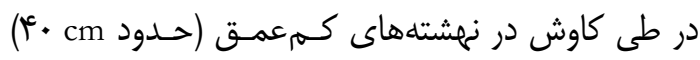

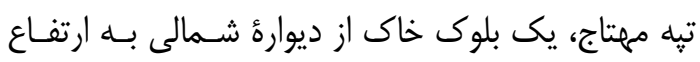
مط كه r cm

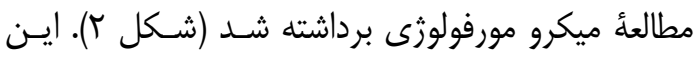

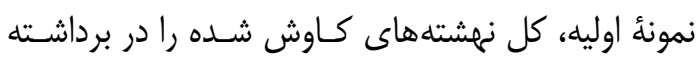

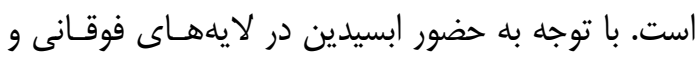

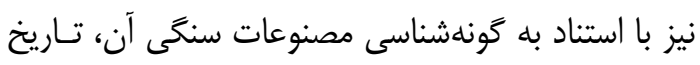

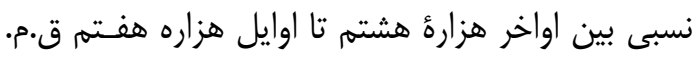

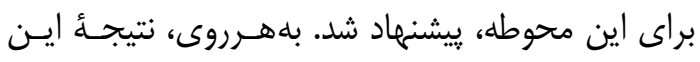

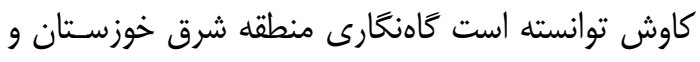

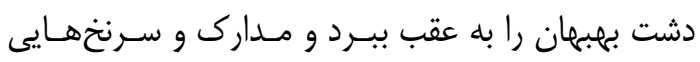

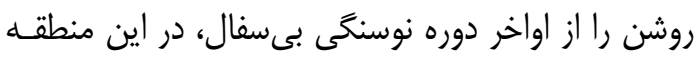

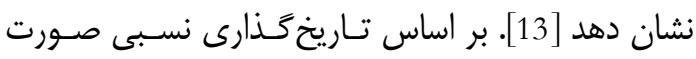

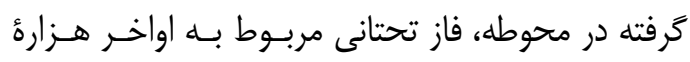

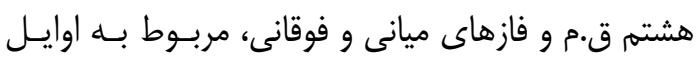

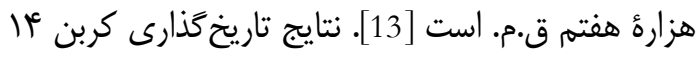

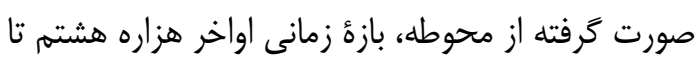

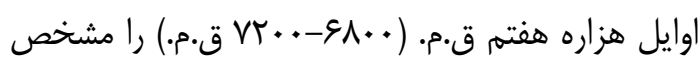

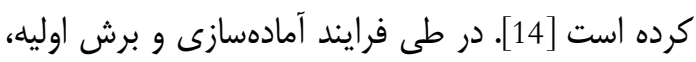

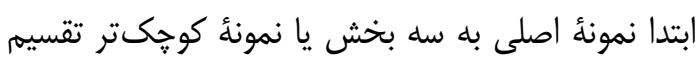

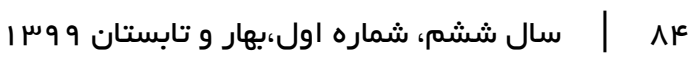


دو فصلنامه يزوهه باستانسنجى

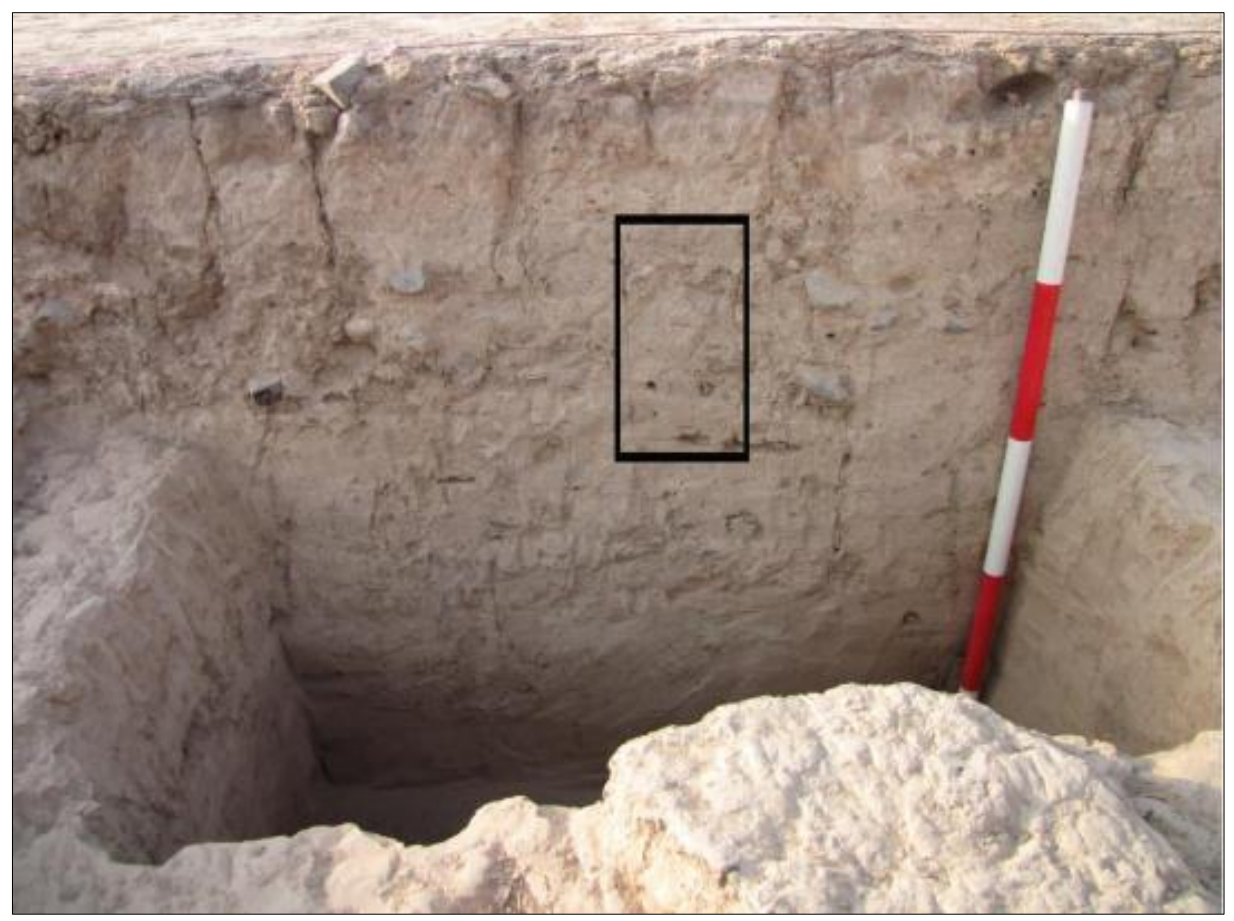

شكل r: محل برداشت نمونهُ اوليه ميكرو مورفولوزى (Darabi, 2015:160)

Fig.2: The location of micromorphology sample of Tapeh Mahtaj (after Darabi, 2015: 160)

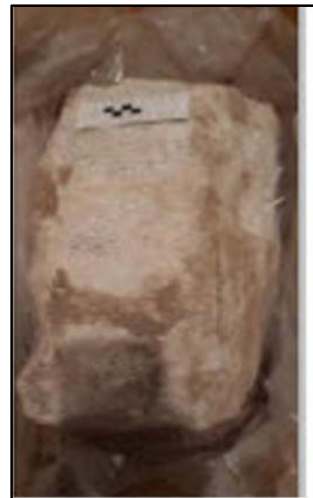

1

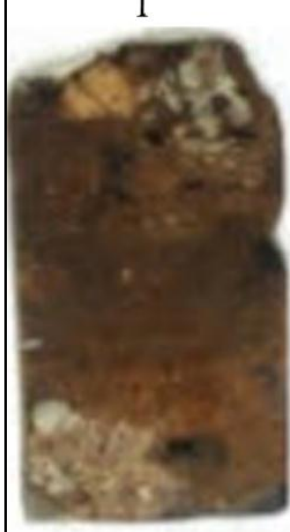

5

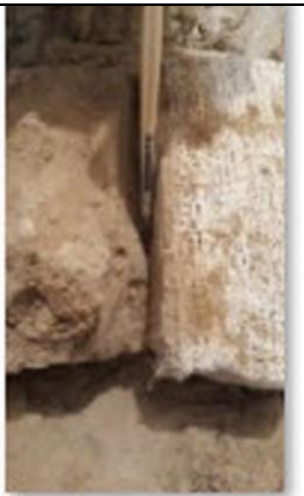

2

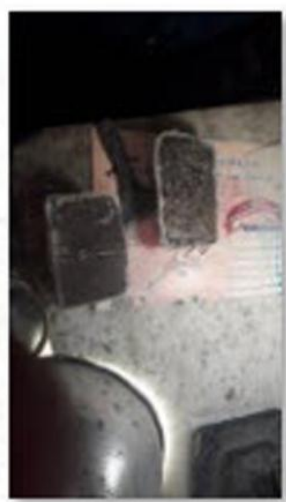

6

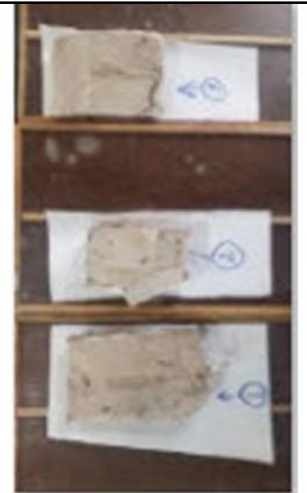

3

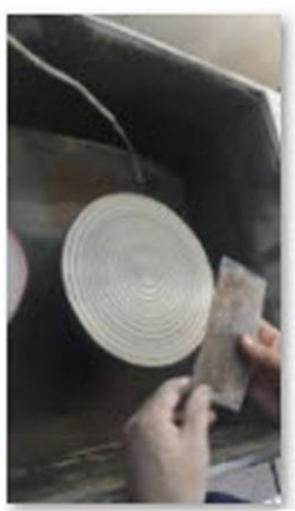

7

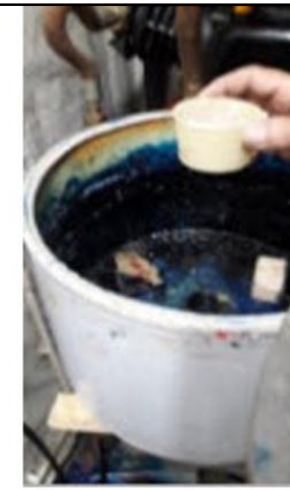

4

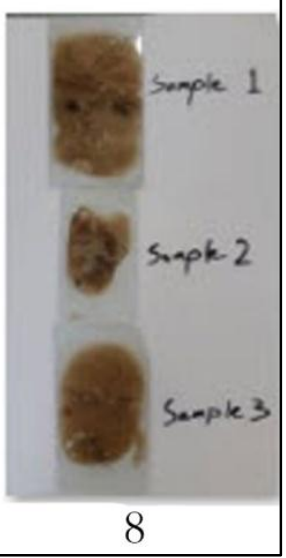

8

شكل س: مراحل تميهسازى مقاطع نازى

Fig.3: Thin Section Preparation stages

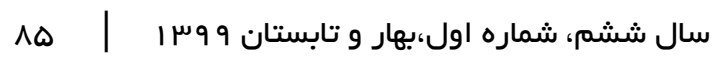


همراه بــا آن نشـانكر فعاليـتهـاى سـكونتكاهى انسـانى

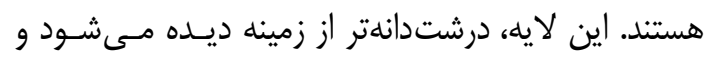

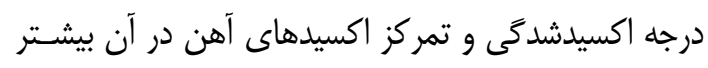

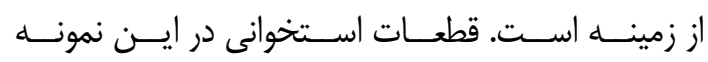

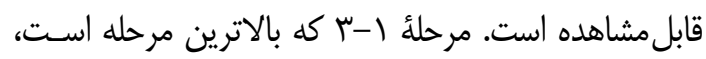

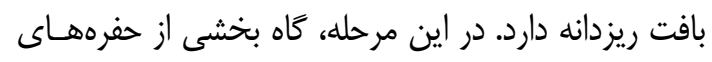

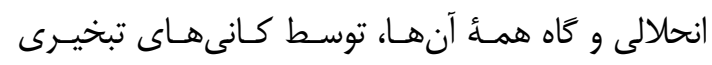

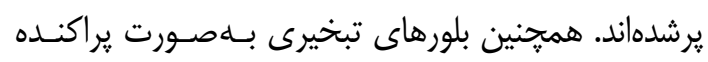

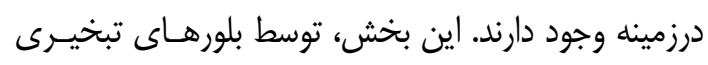

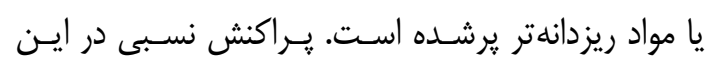

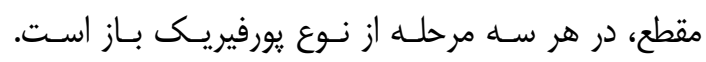
يافتههاى مربوط به مقطع شماره سه در شـكل (ه) آمــده

ه- r. نمونهُ شماره r: اين مقطع، شـامل دو مرحلـهـ

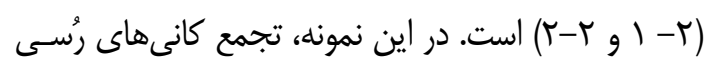

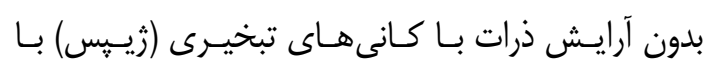

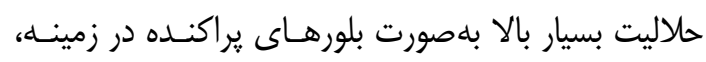

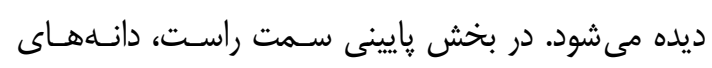

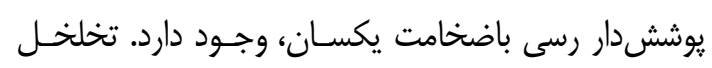

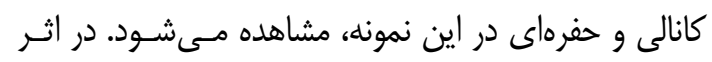

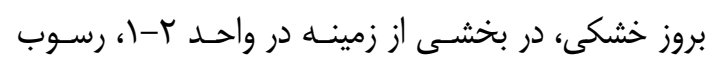

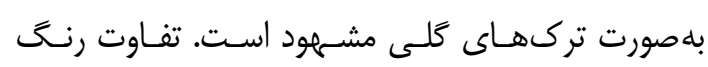

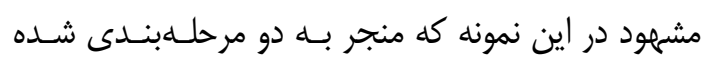

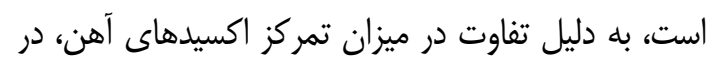

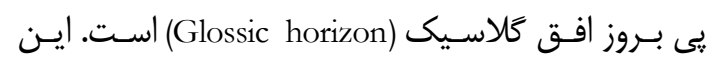

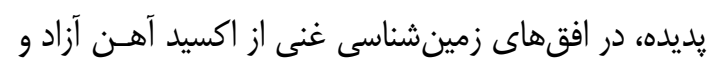

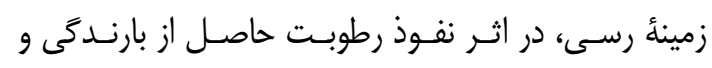

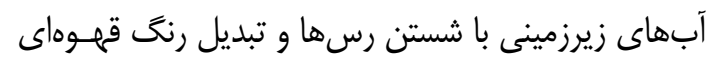

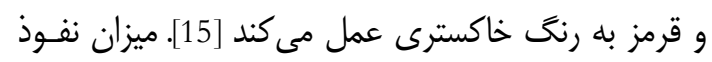

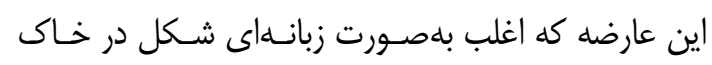

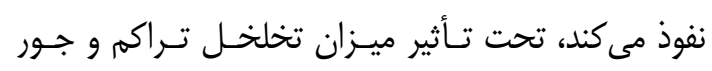

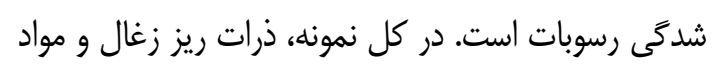

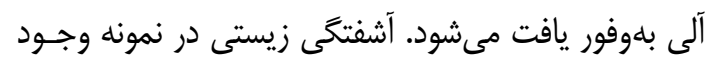

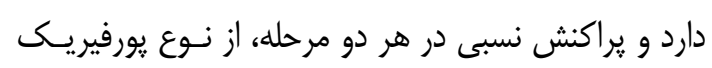

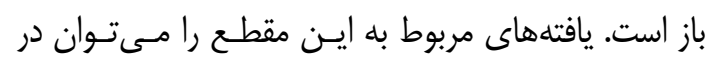
شكل (ধ) ديد.

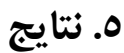

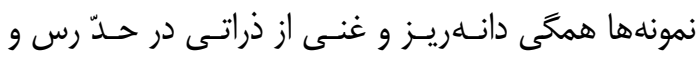

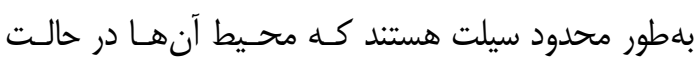

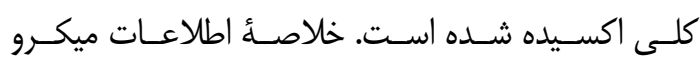

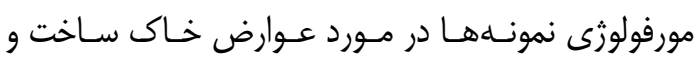

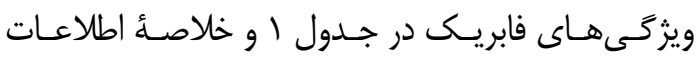

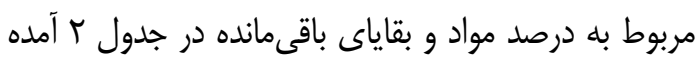
است. مراحل نهشته كذارى يا مراحل لايهنكارانسه از قـديم

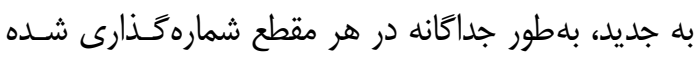

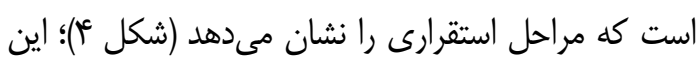
كار درواقع نوعى "ريز لايهنگارى " (Micro-Stratigraphy)

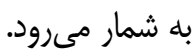
ه-1. نمونهٔ شماره ا: اين نمونه به سه مرحلة رسوبى

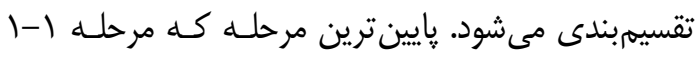

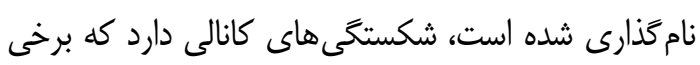

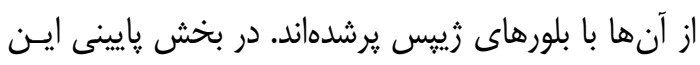

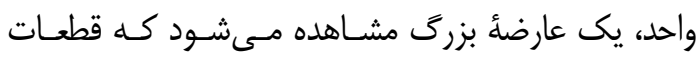

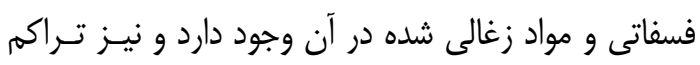

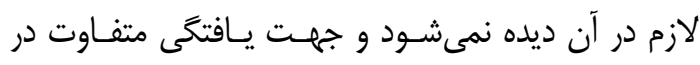
ذرات خاك به نسبت زمينه وجود دارد، كه همكى ايـنهـا

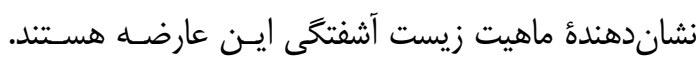

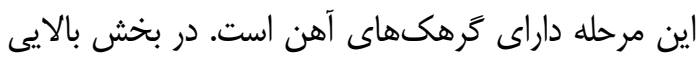

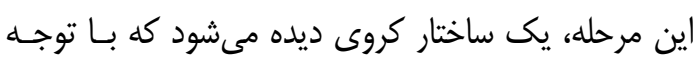

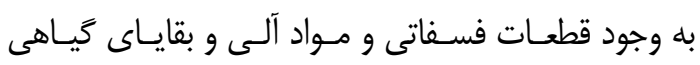

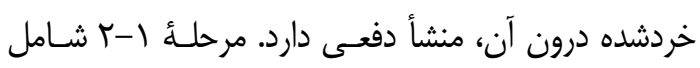

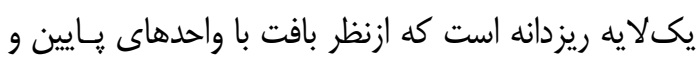

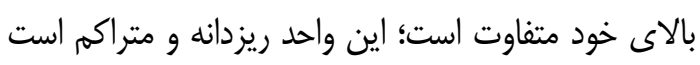

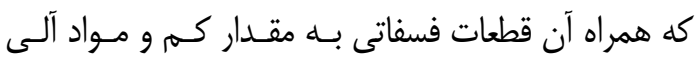

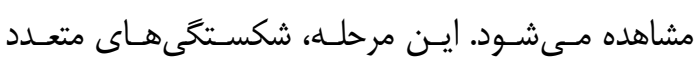

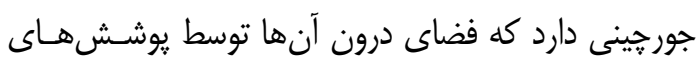

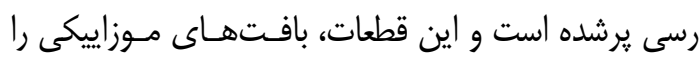

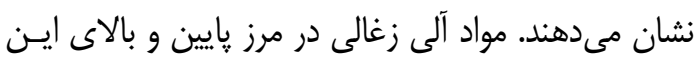
واحد، مشاهده مىشوند. در اين بخش، يكى ئن ساختار حفـره

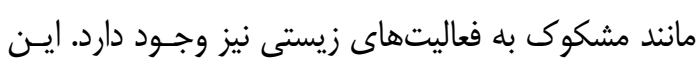

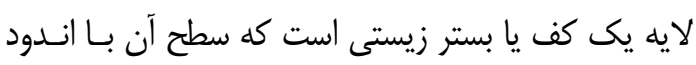

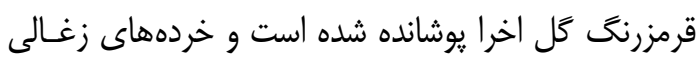

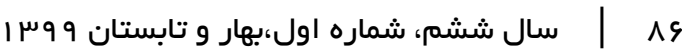


مرحلــه مــواد دفعسى و قطعــات فسـفاتى شـــه، دارد و

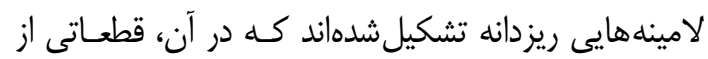

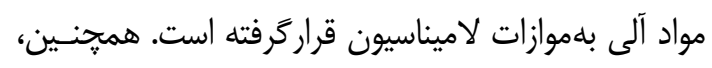

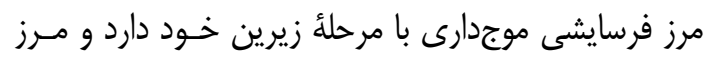

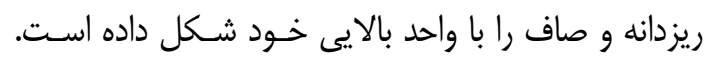

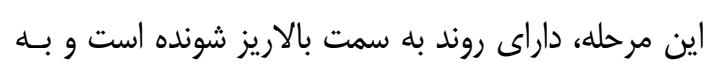

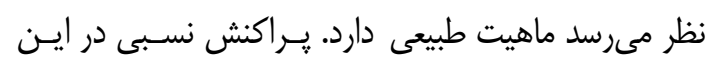
مرحله، از نوع يورفيريك بافاصله دوبل - باز است.

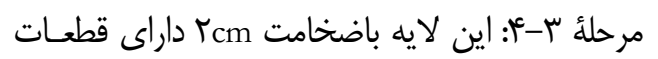

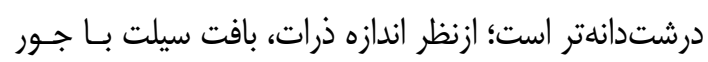

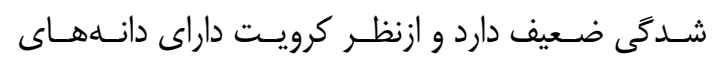

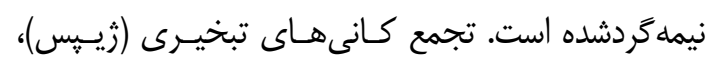

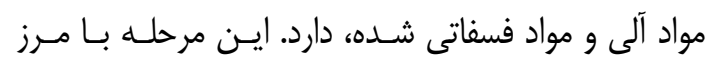

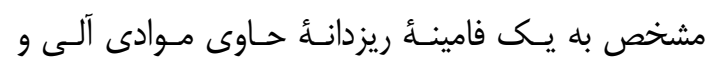

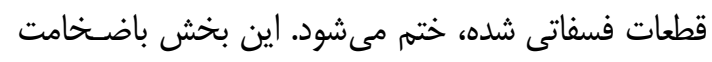

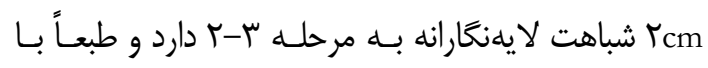

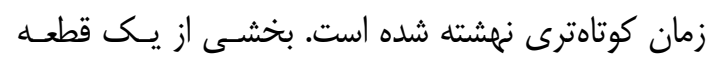

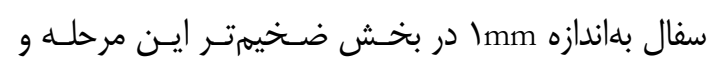

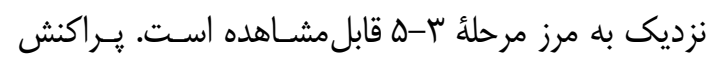
نسبى، از نوع يورفيريك بافاصلة دوبل - باز است.

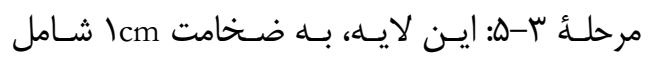

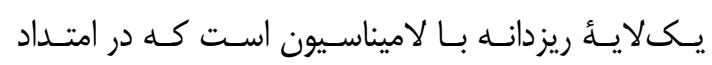

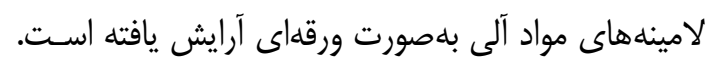

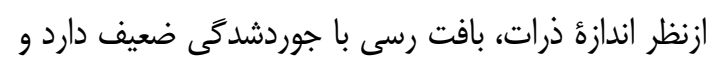

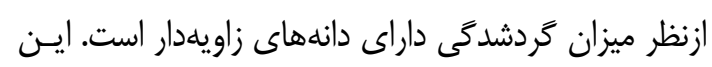

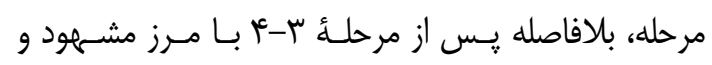

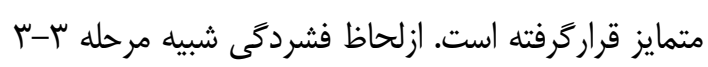

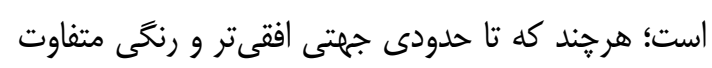

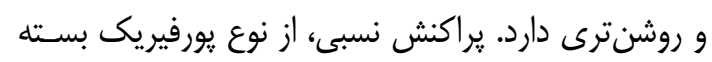
تا يورفيريك بافاصله واحد است.

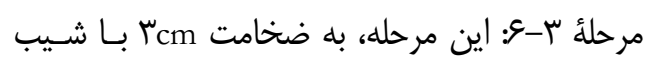

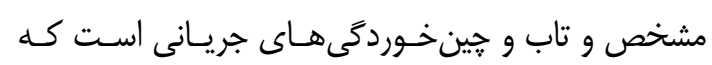

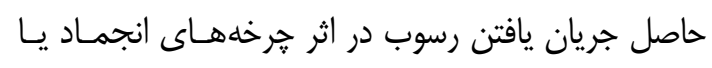
ذوب در بخش سطحى رسوبات است. ازنظر انـدازء ذرات،

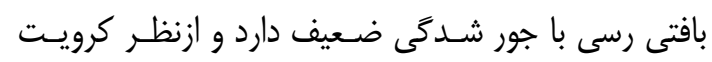

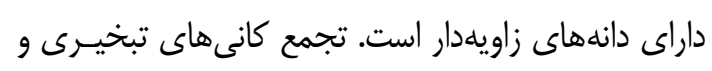

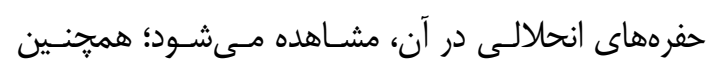
$\wedge \vee$
ه- ". نمونهُ شماره "ّ: در نمونه شمارة "ّ، شاهد يـك

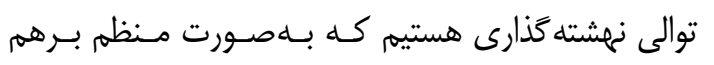

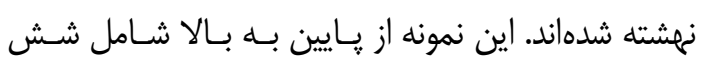

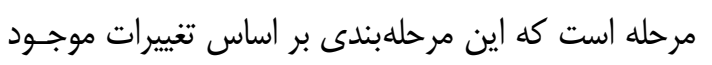

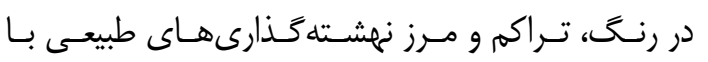
لايههاى فرهنكى ايجادشده است.

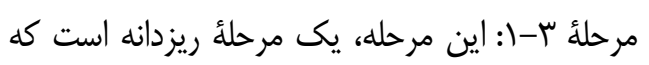
با ناييوستخى فرسايشى و با لامينهاى از مواد آلى يا زغالى مانى با مرحلهاى داراى دو مرز است. اين مرحلـه ازنظـر انـازئ

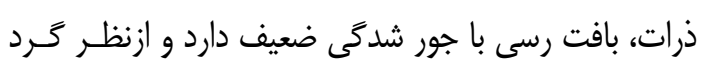

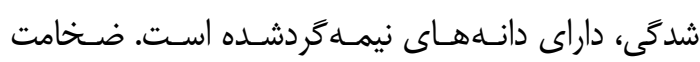

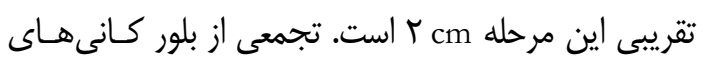

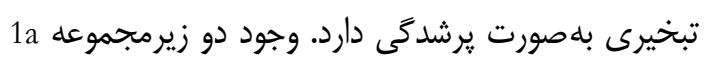

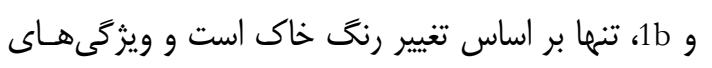
فابريك در هر دوثابت است. يراكنش نسبى در اين مرحله، تئه

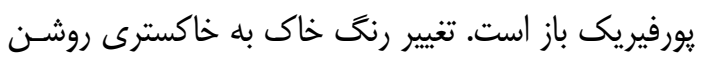

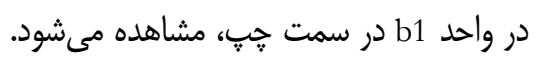

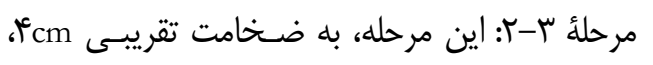

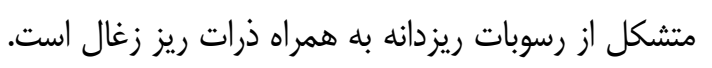

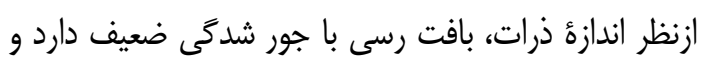

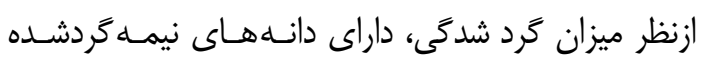

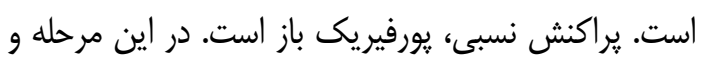

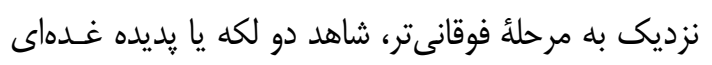

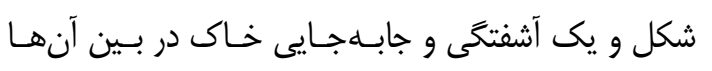

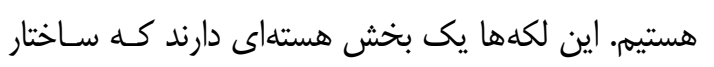

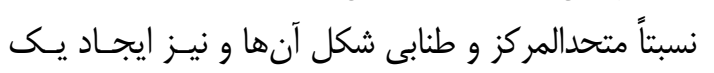

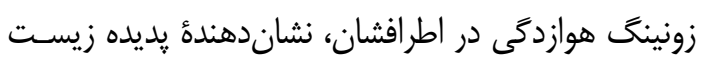
آشفتخى (Bioturbation) است كه توسط مواد آلى، مـواد

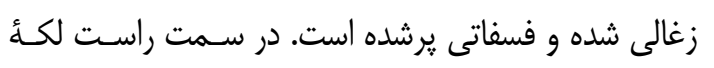

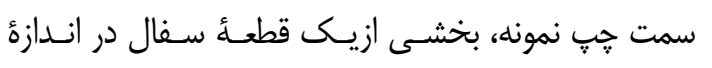

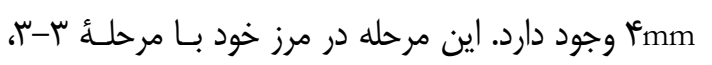
داراى آثار قطعات استخوانى فسفات شده است.

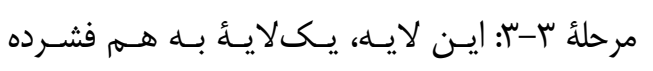

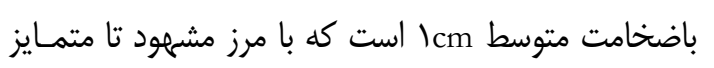

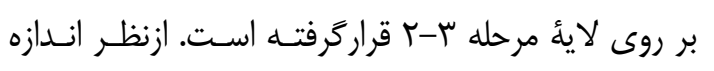
ذرات، بافت رسى با جور شدى ضع ضعيف دارد و ازنظر ميزان

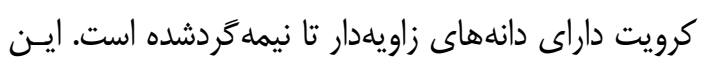


در اين مرحلـه، ارتبـاط عمـق لايسهـــاى باسـتانى و

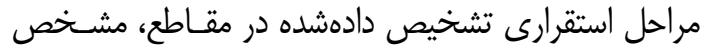
مىشود؛ بهمنظور درك بهتــر از عمـق مراحـل تشـخيص

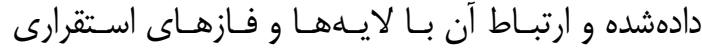

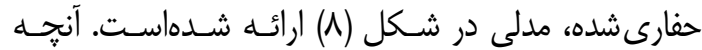
مشخص است انطبـاق كـفهـاى مشهمود در مقـاطع بـاــا

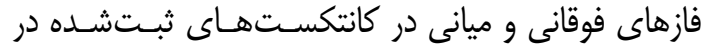
كزارش كاوش است. فّ از از قسمت انتهايى نمونه، هنحام
قطعات آلى زغالى شــده در زمينـهـ يراكــــه اسـت. ازنظـــ

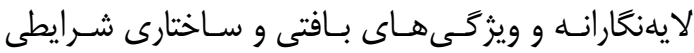

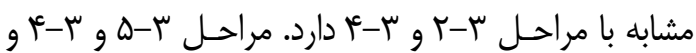
بخشى از ب-ץ شكسته شدهاند كه توسط مواد مرحلئ ب-9

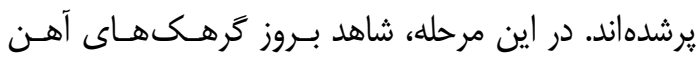

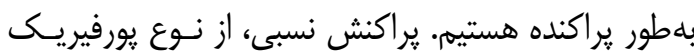

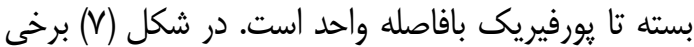
از يافتهاى نمونهُ يك آورده شده است.

جدول ا: خلاصه اطلاعات ساختار و ويزَى هاى فابريك

Table 1: Fabric Information of the Samples.

\begin{tabular}{|c|c|c|c|c|c|c|c|}
\hline \multirow{2}{*}{$\begin{array}{l}\text { Sample } \\
\text { Sample }\end{array}$} & \multirow{2}{*}{ مرحله } & \multicolumn{3}{|c|}{$\begin{array}{c}\text { عوارض خاك ساخت } \\
\text { Pedofeatures }\end{array}$} & \multicolumn{3}{|c|}{$\begin{array}{c}\text { ساختار } \\
\text { Structure }\end{array}$} \\
\hline & & $\begin{array}{l}\text { ازندازئ } \\
\text { Particle } \\
\text { Size } \\
\end{array}$ & يرشدىى & $\begin{array}{l}\text { Nodule } \\
\text { Nodul }\end{array}$ & $\begin{array}{l}\text { אرد شدگى } \\
\text { Roundness }\end{array}$ & جور شدىى & $\begin{array}{l}\text { يراكنش نسبى } \\
\text { C/F }\end{array}$ \\
\hline \multirow{6}{*}{3} & $1-3$ & $\begin{array}{l}\text { رس } \\
\text { Clay }\end{array}$ & 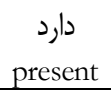 & ندارد & $\begin{array}{c}\text { دانdهاى نيمه گرد شده } \\
\text { Sub-rounded }\end{array}$ & \begin{tabular}{|l} 
جور شدگى ضعيف \\
Poorly sorting \\
\end{tabular} & $\begin{array}{c}\text { يورفيريك باز } \\
\text { Open Porphyric } \\
\end{array}$ \\
\hline & $2-3$ & 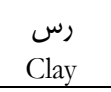 & $\begin{array}{l}\text { ندارد } \\
\text { non }\end{array}$ & ندارد & $\begin{array}{c}\text { دانههاى نيمه گرد شده } \\
\text { Sub-rounded }\end{array}$ & \begin{tabular}{|l} 
جور شدگى ضعيف \\
Poorly sorting \\
\end{tabular} & $\begin{array}{c}\text { يورفيريك باز } \\
\text { Open Porphyric }\end{array}$ \\
\hline & $3-3$ & $\begin{array}{l}\text { سيلت } \\
\text { Silt }\end{array}$ & 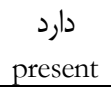 & ندارد & $\begin{array}{l}\text { كرد شدَى زاويه تا نيماءكردشدهاه } \\
\text { Sub-rounded, Sub-angular }\end{array}$ & جور شدگى ضعيف & 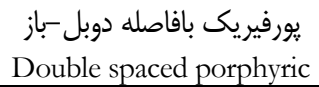 \\
\hline & $4-3$ & - & $\begin{array}{c}\text { دارد } \\
\text { present } \\
\end{array}$ & ندارد & \begin{tabular}{|c|} 
نيملكردشده \\
Sub-rounded \\
\end{tabular} & \begin{tabular}{|l|} 
Pور شدكى ضعيف \\
Poorly sorting \\
\end{tabular} & $\begin{array}{l}\text { يورفيريك بافاصله دوبل - باز } \\
\text { Double spaced porphyric }\end{array}$ \\
\hline & $5-3$ & $\begin{array}{l}\text { (2lay } \\
\text { Cla }\end{array}$ & 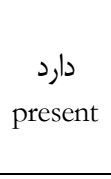 & 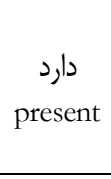 & $\begin{array}{l}\text { دانههاى زاويهدار } \\
\text { Angular }\end{array}$ & جور شدكى ضعيف & $\begin{array}{c}\text { بورفيريك بسته تا يورفيريك } \\
\text { بافاصله واحد } \\
\text { Close porphyric-single } \\
\text { spased porphyric }\end{array}$ \\
\hline & $6-3$ & $\begin{array}{l}\text { رس } \\
\text { Clay }\end{array}$ & $\begin{array}{l}\text { ندارد } \\
\text { non }\end{array}$ & 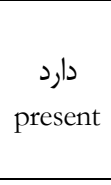 & $\begin{array}{l}\text { دانههاى زاويهدار } \\
\text { Angular }\end{array}$ & جور شدگى ضعيف & $\begin{array}{l}\text { يورفيريك بسته تا يورفيريك } \\
\text { بافاصله واحد } \\
\text { Close porphyric-single } \\
\text { spased porphyric }\end{array}$ \\
\hline \multirow{2}{*}{2} & $1-2$ & 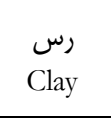 & ندارد & 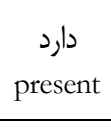 & \multirow{2}{*}{ 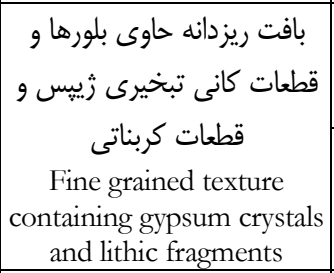 } & $\begin{array}{c}\text { جور شدگى متوسط } \\
\text { Moderately } \\
\text { sorting }\end{array}$ & $\begin{array}{c}\text { يورفيريك باز } \\
\text { Open Porphyric }\end{array}$ \\
\hline & $2-2$ & $\begin{array}{l}\text { رس } \\
\text { Clay }\end{array}$ & ندارد & ندارد & & \begin{tabular}{|c|} 
جور شدگى متوسط \\
Moderately \\
sorting
\end{tabular} & $\begin{array}{c}\text { يورفيريك باز } \\
\text { Open Porphyric }\end{array}$ \\
\hline \multirow{3}{*}{1} & $1-1$ & $\begin{array}{l}\text { رس } \\
\text { Clay }\end{array}$ & $\begin{array}{c}\text { P دارد } \\
\text { present }\end{array}$ & $\begin{array}{c}\text { present } \\
\text { pres }\end{array}$ & $\begin{array}{c}\text { دانههاى زاويهدار تا نيمه گرد } \\
\text { Sub-rounded } \\
\text { Suد }\end{array}$ & جور شدكى ضعيف & $\begin{array}{c}\text { يورفيريك باز } \\
\text { Open Porphyric }\end{array}$ \\
\hline & $2-1$ & $\begin{array}{l}\text { (2lay } \\
\text { Cla }\end{array}$ & $\begin{array}{c}\text { دارد } \\
\text { present }\end{array}$ & ندارد & $\begin{array}{c}\text { Fine grained texture, Sub- } \\
\text { rounded }\end{array}$ & \begin{tabular}{|c|}
$\begin{array}{c}\text { Moderately } \\
\text { sorting }\end{array}$ \\
\end{tabular} & $\begin{array}{c}\text { يورفيريك باز } \\
\text { Open Porphyric }\end{array}$ \\
\hline & $3-1$ & $\begin{array}{l}\text { رس } \\
\text { Clay }\end{array}$ & 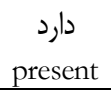 & ندارد & $\begin{array}{l}\text { ريزدانه و دانههاى زاويلهدار } \\
\text { Fine texture, Angular }\end{array}$ & \begin{tabular}{|c|} 
جور شدگى ضعيف \\
Poorly sorting \\
\end{tabular} & $\begin{array}{c}\text { يورفيريك باز } \\
\text { Open Porphyric }\end{array}$ \\
\hline
\end{tabular}


جدول r: درصد فراوانى مواد بهدستآمده از مقاطع نازك

Table 2: The Amount of Achieved Material from Thin Sections

\begin{tabular}{|c|c|c|c|c|c|c|c|}
\hline \multirow{2}{*}{$\begin{array}{c}\text { نمونه } \\
\text { Sample }\end{array}$} & \multirow[b]{2}{*}{$\begin{array}{l}\text { مرحله } \\
\text { Stage }\end{array}$} & $\begin{array}{l}\text { Eij } \\
\text { Color }\end{array}$ & \multicolumn{5}{|c|}{$\begin{array}{l}\text { بقاياى مواد موجود در نمونهها } \\
\text { Fine Mineral Constituents }\end{array}$} \\
\hline & & $\begin{array}{c}\text { Hue } \\
\text { Value/Chroma }\end{array}$ & $\begin{array}{c}\text { زغال } \\
\text { Charcoal } \\
(\%)\end{array}$ & $\begin{array}{c}\text { سفال } \\
\text { Ceramic } \\
(\%)\end{array}$ & $\begin{array}{c}\text { مواد دفعى } \\
\text { Feces } \\
(\%)\end{array}$ & $\begin{array}{c}\text { استخوان } \\
\text { Bone } \\
(\%)\end{array}$ & $\begin{array}{c}\text { فسفات } \\
\text { Phosphate } \\
(\%)\end{array}$ \\
\hline \multirow{6}{*}{3} & $1-3$ & $\begin{array}{c}\text { Yellowish Brown } \\
7 / 5 \mathrm{YR} 6 / 3 \\
\end{array}$ & 5 & 0 & 2 & 5 & 2 \\
\hline & $2-3$ & \begin{tabular}{ll}
\multicolumn{2}{c}{ Brown } \\
$10 \mathrm{YR}$ & $5 / 4$ \\
\end{tabular} & 5 & 1 & 5 & 5 & 5 \\
\hline & $3-3$ & \begin{tabular}{lr}
\multicolumn{2}{c}{ Reddish Brown } \\
5YR & $5 / 3$ \\
\end{tabular} & 5 & 0 & 2 & 0 & 2 \\
\hline & $4-3$ & $\begin{array}{c}\text { Light Yellowish Brown } \\
\text { 10YR }\end{array}$ & 3 & 2 & 2 & 5 & 5 \\
\hline & $5-3$ & \begin{tabular}{ll}
\multicolumn{2}{c}{ Brown } \\
10YR & $5 / 3$ \\
\end{tabular} & 2 & 0 & 2 & 2 & 2 \\
\hline & $6-3$ & \begin{tabular}{l}
\multicolumn{3}{c}{ Yellowish Brown } \\
10YR
\end{tabular} & 5 & 0 & 5 & 2 & 3 \\
\hline \multirow[t]{2}{*}{2} & $1-2$ & \begin{tabular}{lr}
\multicolumn{2}{c}{ Reddish Brown } \\
$2.5 \mathrm{YR}$ & $5 / 4$
\end{tabular} & 3 & 0 & 5 & 5 & 5 \\
\hline & $2-2$ & $\begin{array}{l}\text { Light Brownish Gray } \\
10 \mathrm{YR}\end{array}$ & 0 & 0 & 2 & 0 & 0 \\
\hline \multirow{3}{*}{1} & $1-1$ & \begin{tabular}{lr}
\multicolumn{3}{c}{ Yellowish Brown } \\
$10 \mathrm{YR}$ & $5 / 4$ \\
\end{tabular} & 2 & 0 & 20 & 5 & 5 \\
\hline & $2-1$ & \begin{tabular}{lr}
\multicolumn{2}{c}{ Reddish Brown } \\
$2.5 \mathrm{YR}$ & $4 / 4$ \\
\end{tabular} & 10 & 0 & 0 & 0 & 0 \\
\hline & $3-1$ & \begin{tabular}{lr}
\multicolumn{3}{c}{ Yellowish Brown } \\
10YR & $5 / 4$ \\
\end{tabular} & 3 & 0 & 2 & 2 & 2 \\
\hline
\end{tabular}

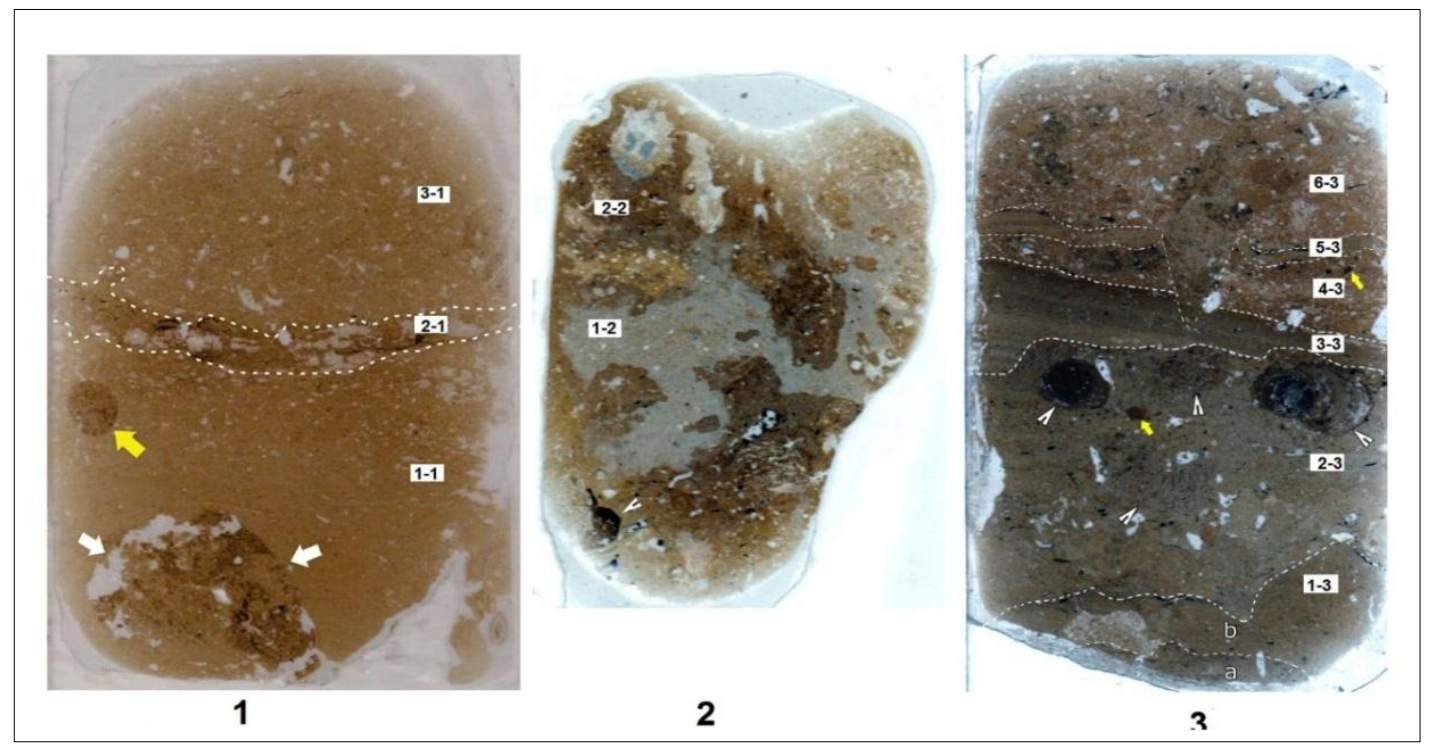

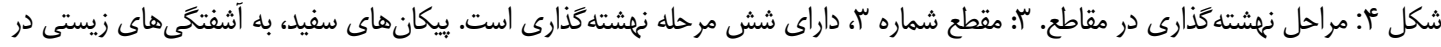

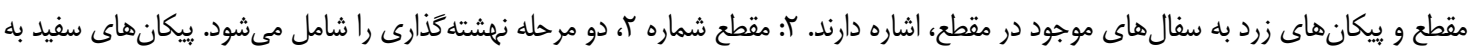

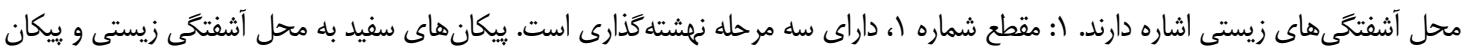
زرد به مواد دفعى موجود در مرحلئ تحتانى اشاره دارند.

Fig.4: Sediment Stages in Thin Sections. Depositing stages in sections (Right to Left). 3) Section No. 3 has VI stages of deposition. The white arrows refer to the bioturbation and the yellow arrows to the pottery in the section. 2) Section 2 includes II stages of deposition. White arrows indicate the location of bioturbation. 1) Section No. 1 has III stages of deposition. White arrows indicate the location of the bioturbation and yellow arrows refer to the dung remain in the lower stage. 


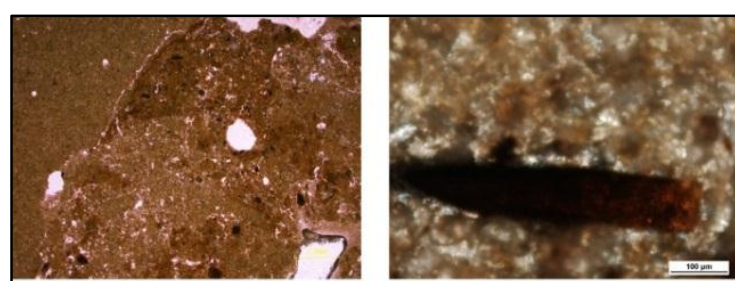

4

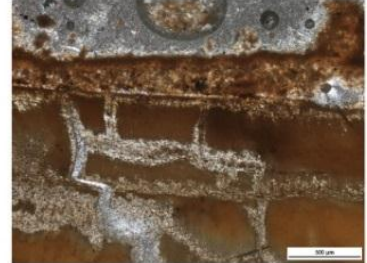

2

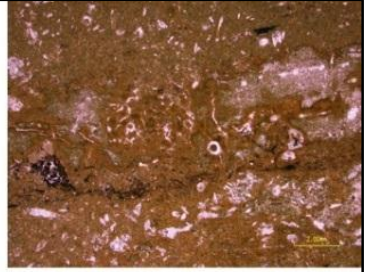

1

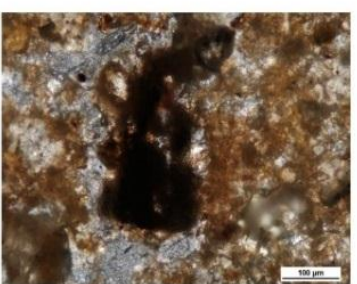

7

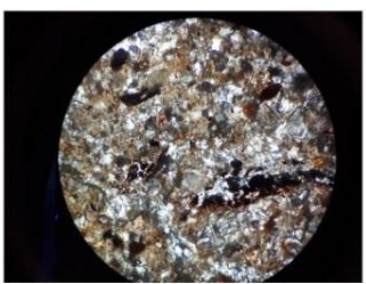

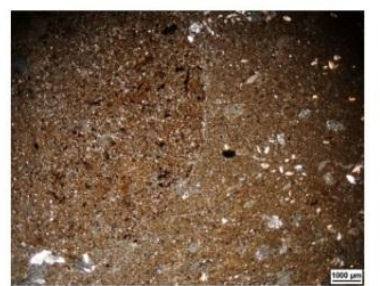

5

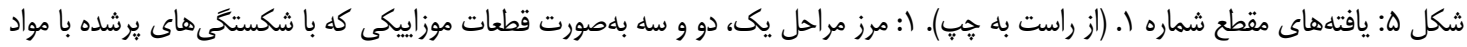

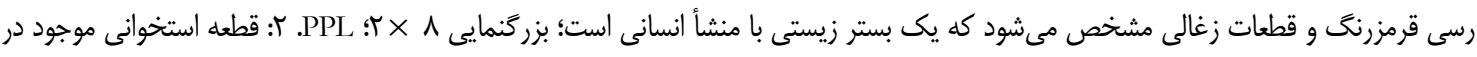

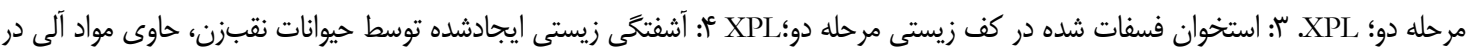

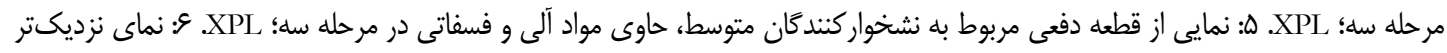

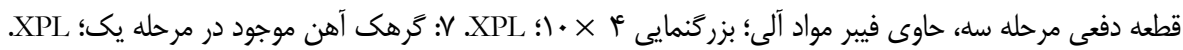

Fig.5: Sample 1 Findings (Right to Left). 1) The boundaries between stages I, II and III in the form of mosaic fragments characterized by fractures filled with red clay and charcoal fragments indicating an anthropogenic origin, likely living floors; Magnification 8×2, PPL; 2) A bone fragment in stage II, XPL; 3) Phosphatized bone in the living floor of stage II, XPL; 4)

Bioturbation by burrowing animals, filled with organic material, in stage III, XPL; 5) View of dung fragment, containing organic matter and phosphate, related to medium-sized Ruminantia in stage III, XPL; 6) Closer view of the dung fragment in stage III, containing plant fibers; Magnification 4×10, XPL; 7) Iron nodule in stage I, XPL.

هاشور خورده، محل سنَ جداشده در حين بــرش نمونـهـ

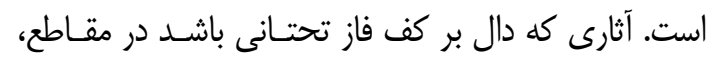

مشاهده نشلد.
برداشت نمونهُ اوليه ازدسترفته است. فاز فوقانى در عمـق

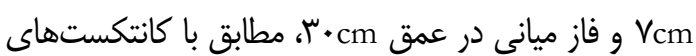

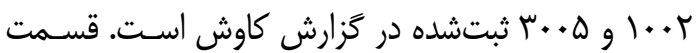

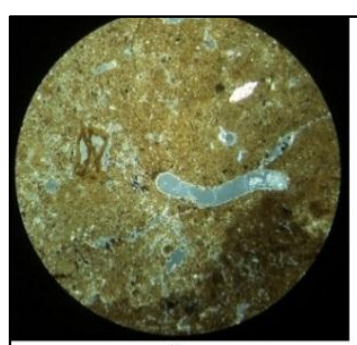

4

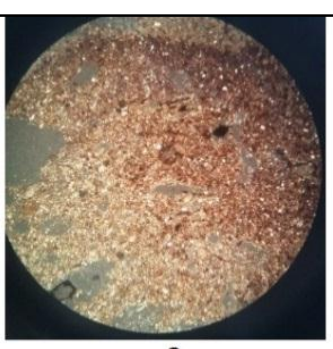

3

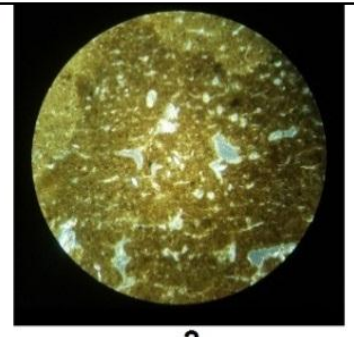

2

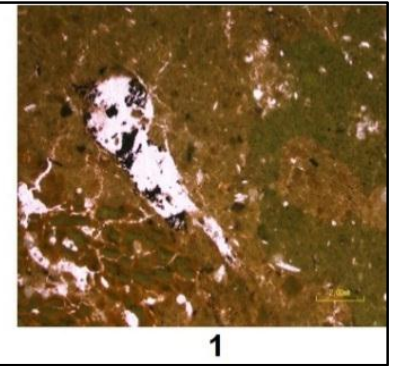

1

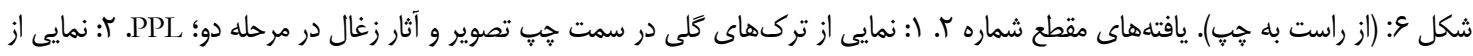

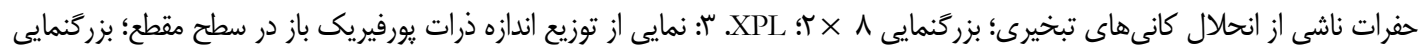

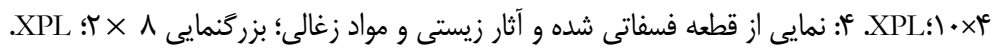

Fig.6: Sample 2 Findings (Right to left). 1(Cross section of mud cracks on the left side of the image along with charcoal remains in stage II, PPL; 2) View of crystal molds resulted from dissolution of evaporite minerals, Magnification 8×2, XPL; 3) Open porphyric c/f related distribution pattern, Magnification $4 \times 10$, XPL; 4) View of phosphatized fragment, biological remains and charred materials, Magnification $8 \times 2$, XPL. 


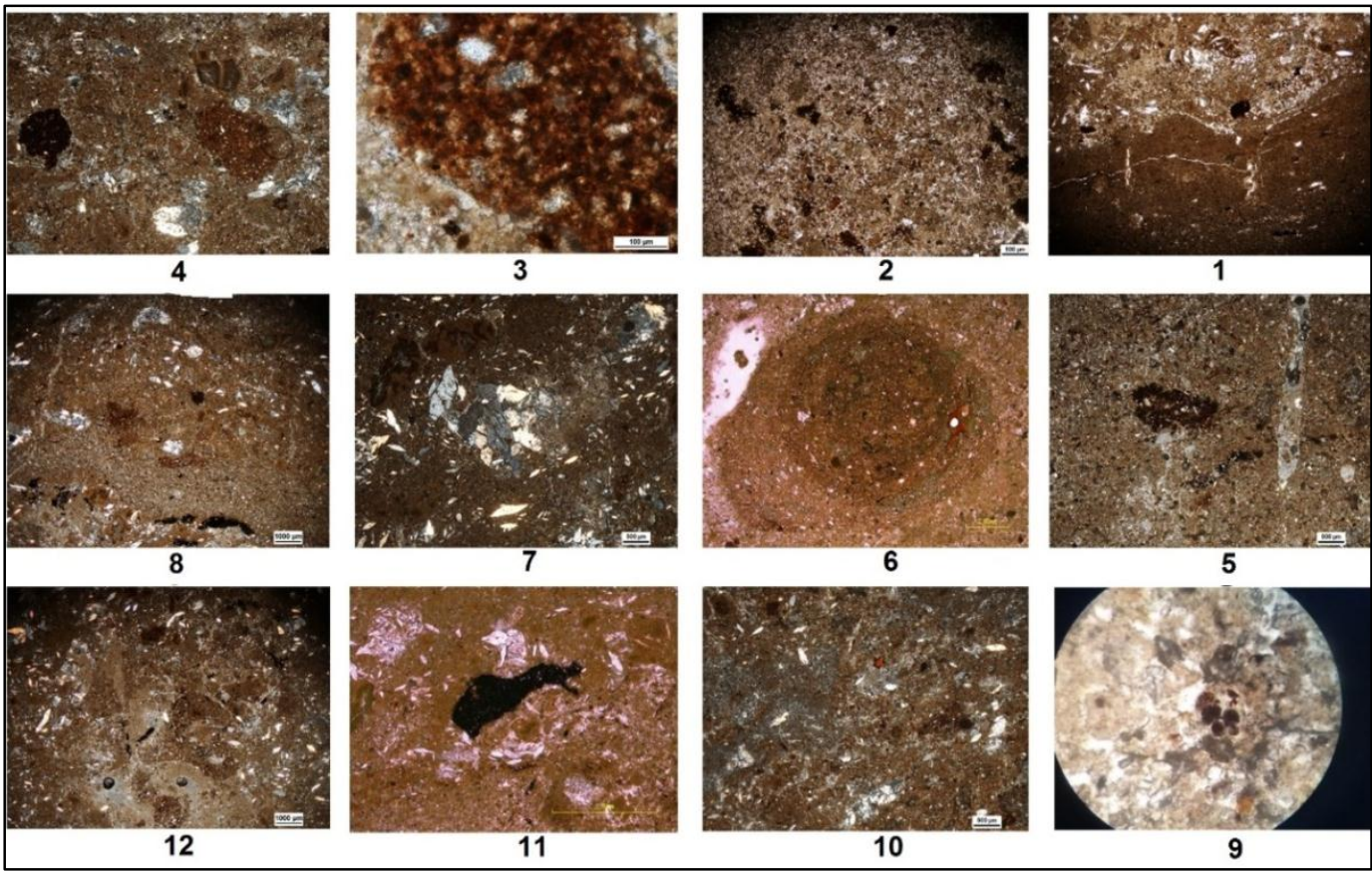

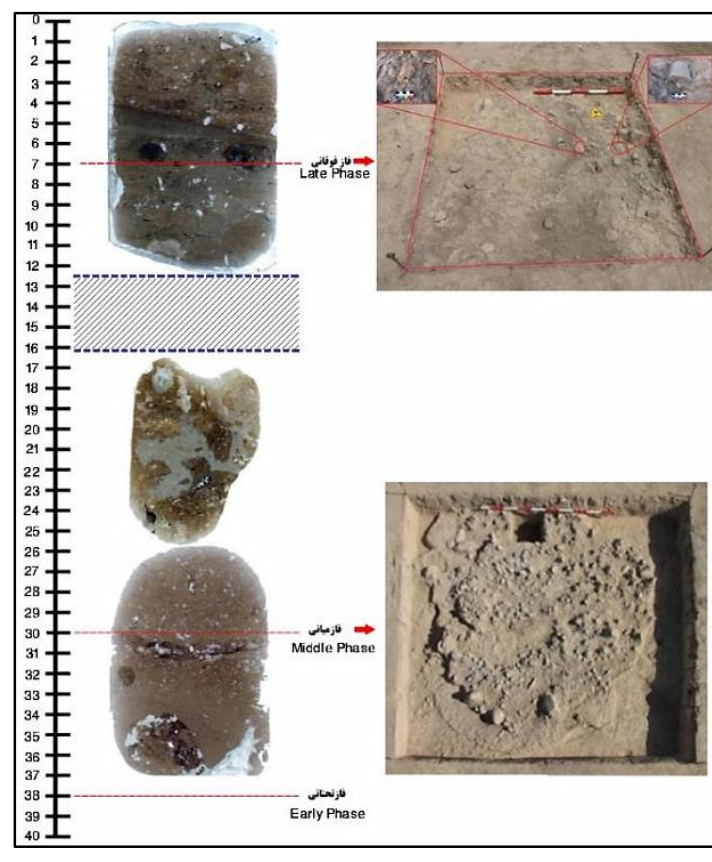

ش شكل م: عمق نمونهها و ارتباط آنها بــا آثـار و فازهـاى معمـارى

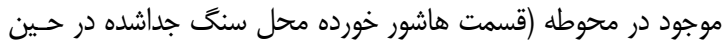

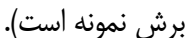
Fig.8: The Depth of Samples and put through Site Architecture Phases (The hatched part shows the location of the isolated stone during cutting the sample).

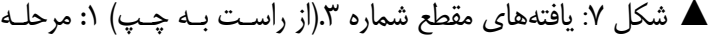

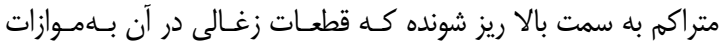

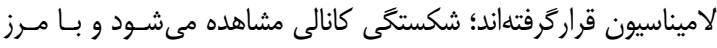

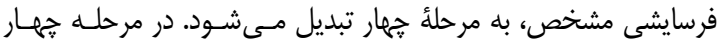

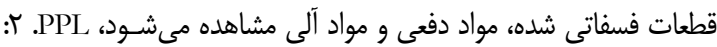

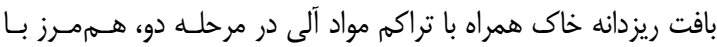

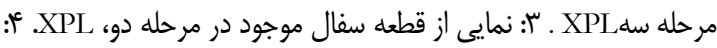

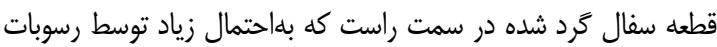

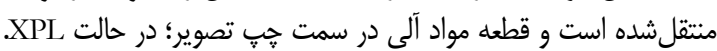

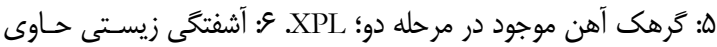

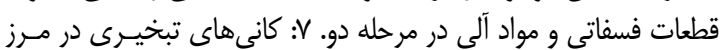

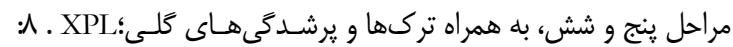

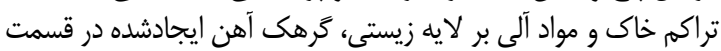

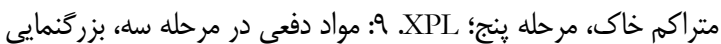

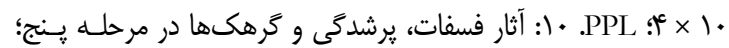

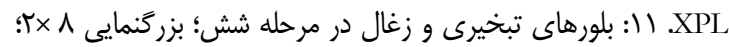

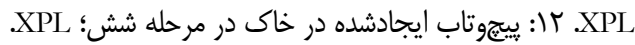
Fig.7: Sample 2 Findings (Right to left). 1) Fining-upward dense layer stage with fine charcoal particles arranged along lamination; A dissolution channel with sharp erosional surface characterizes boundary with stage IV; Stage IV contains phosphatized fragments, feces and organic materials, PPL; 2) Fine-grained soil with abundant organic material in stage II bordering on stage III, XPL; 3) Occurrence of pottery piece in stage II, XPL; 4) A piece of rounded pottery on the right, possibly transported by sediment, and a piece of organic material on the left side of the image, XPL; 5) Iron nodule in stage II, XPL; 6) Bioturbation containing phosphatized and organic material in stage II, XPL; 7) Evaporite minerals at the border between stages IV and VI along with cracks filled with mud, XPL; 8) Compact sediment, containing iron nodule, and organic matter on the surface of living floor, in stage VI, XPL; 9) Fecal pellets in stage III, magnification $10 \times 4$, PPL; 10) Phosphate constituents, fillings and nodules in stage VI, XPL; 11) Evaporite crystals and charcoal in stage VI, Magnification $8 \times 2$, XPL; 12) Cryoturbation features in stage VI, XPL. 
كرهكهاى اكسيد آهن - منخَنز موجود است. شيب ايـن

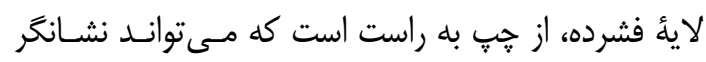

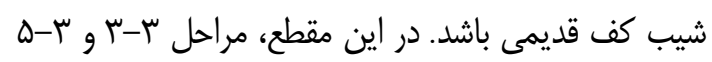

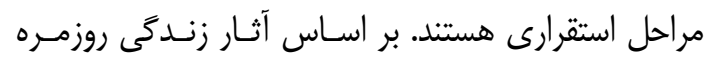

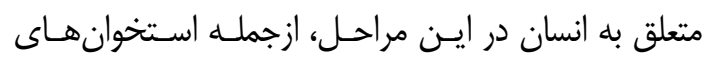

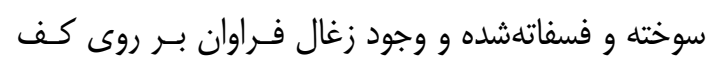

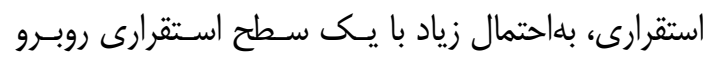

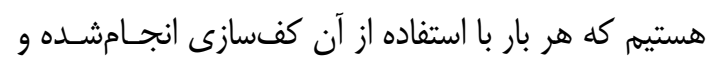

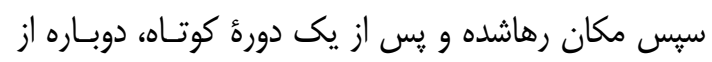

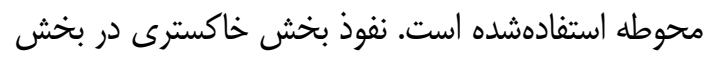

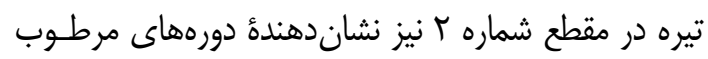

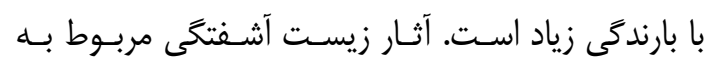

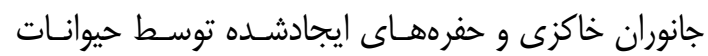

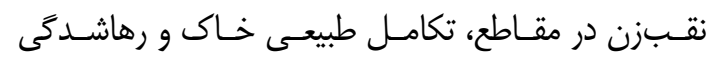
محوطه را در مراحل مختلف بيان مى كند. عـدم تـراكم و و ماكي آرايش و قراركيرى تصادفى بقايا در برخى مراحل، ناشى از ماز

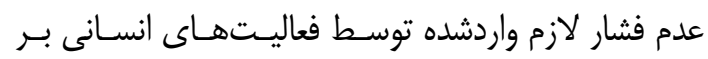
تركيبات اين مراحل و رهاشدگى تناوبى محوطه است. آثار

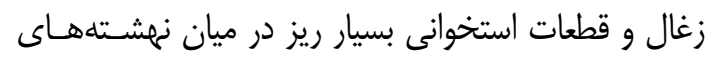

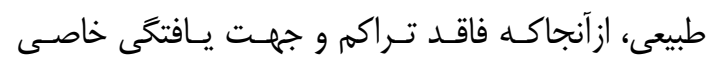

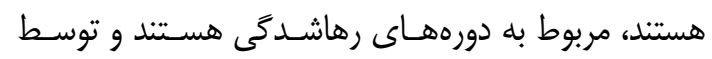

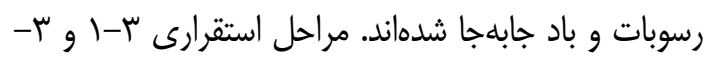

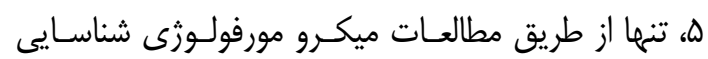
شدند. مقطع شمارة r را بهطور كلى ميتـوان بــهـ زمـانى در

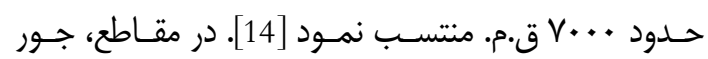

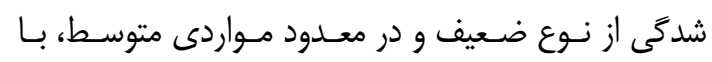
افزايش تخلخل و نفوذيذيرى خاك همراه است كه زمينـه

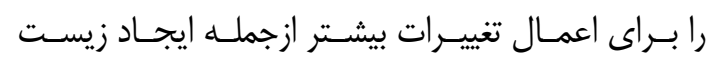

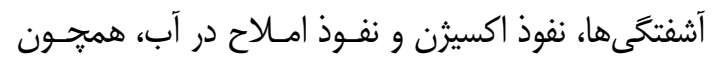

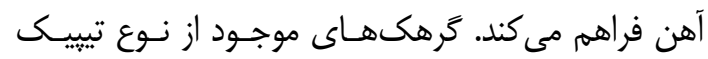

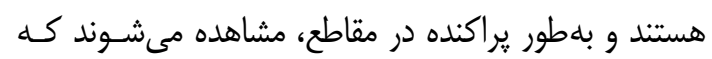

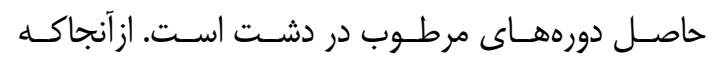
رسوبات مخروطافكنهاى مركز تجمع آبهـاى زيرزمينى دانى است [17]، وجود آبهاى زيرزمينى نيز با نوسان و انتقـال

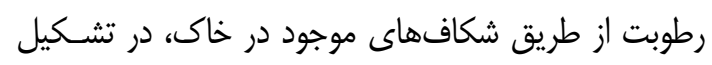

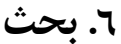

همـانـــور كـهـ از جـــول ا مشـخص اسـت، رسـوبات

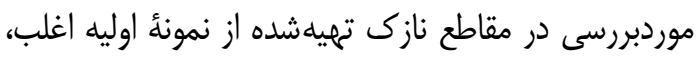

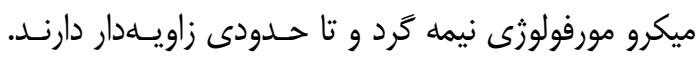

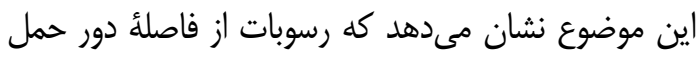

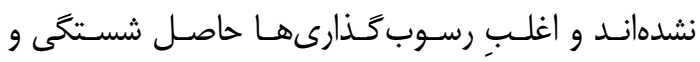
تهنشست رسوبات از قسمت مرتفعتر خود تِّه بوده اسـت.

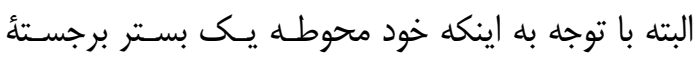

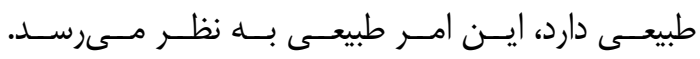

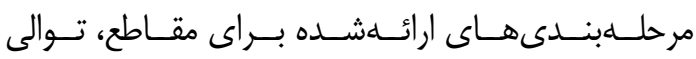

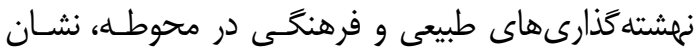

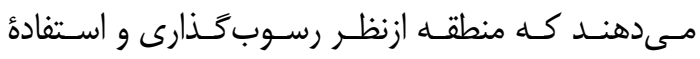
كوتاهمدت توسط انسان دورهٔ نوسنگى از محوطه به شدت دات

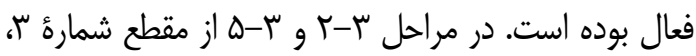
با بروز مقطعى سولفات كلسيه روبـرو هسـتيه كـه نشـان

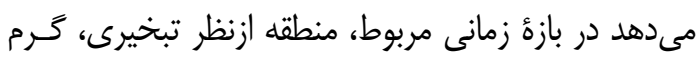

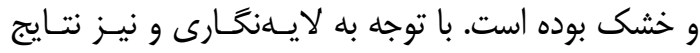

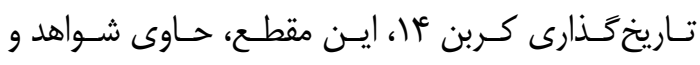

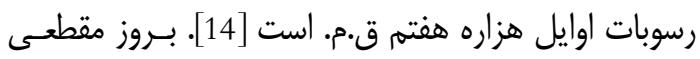

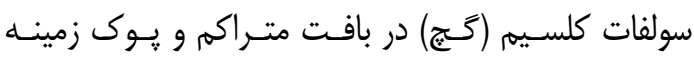

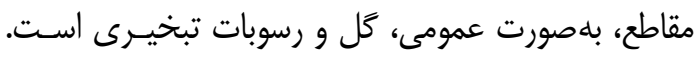

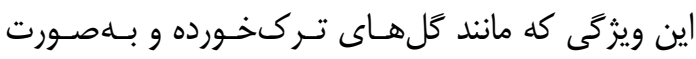

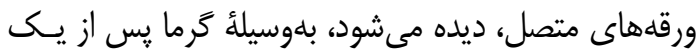

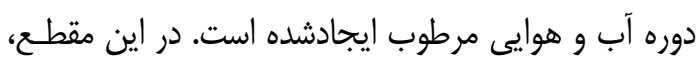

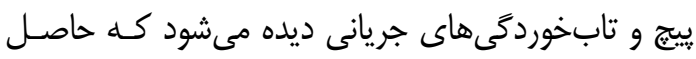

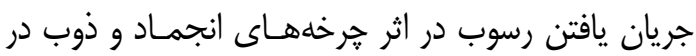

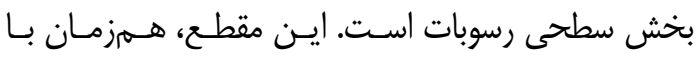

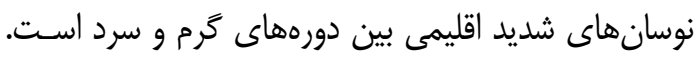

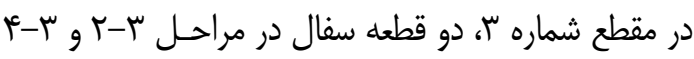
مشاهده مىشود كه به خاطر عدم تيزى و كرد شـدَّى در

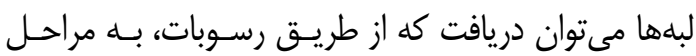
موردنظر حمل شدهاند. قطعه موجود در مرحلئ ب-أ توسط

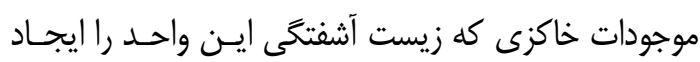

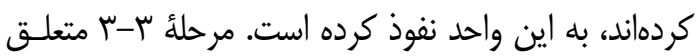
به يك كف سكونتخاهى است؛ دليل اين مسئله خردههاى

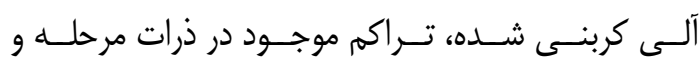




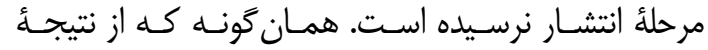
آزمايش هاى زئوشيميايى مشخص است، خاك محوطه در إند

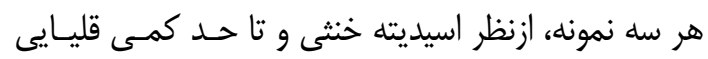

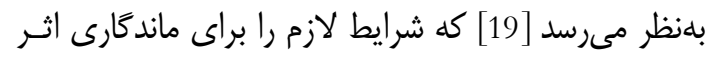

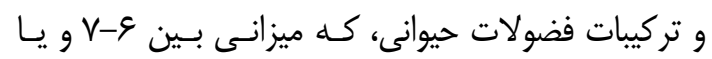

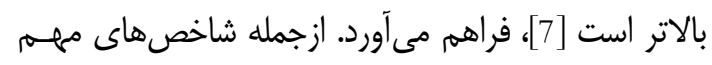
در شناسايى بقاياى دفعى، وجود اسفروليت كلسيت، بقاياى

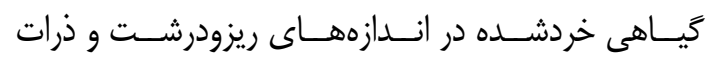
فسفاتهشده موجود در داخل اين عـوارض اسـت، تغييـرات

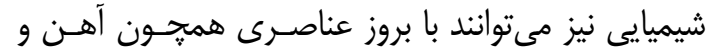

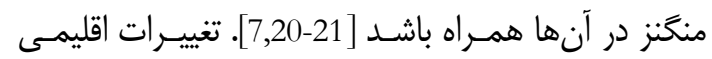

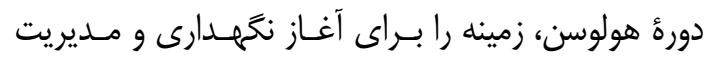

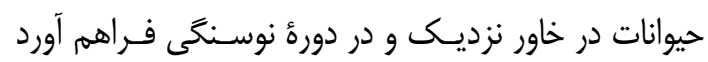

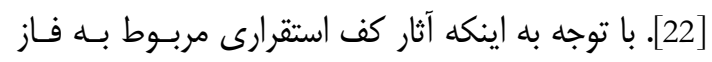

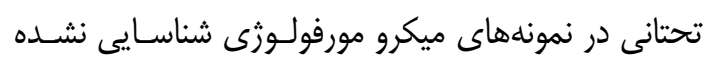

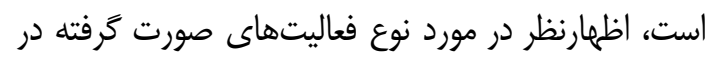

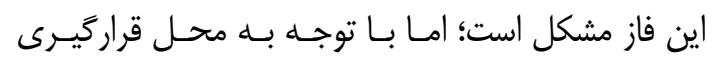

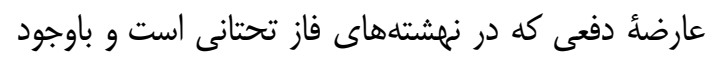

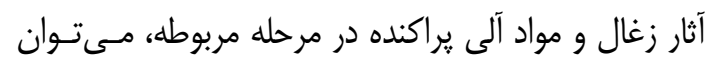
كفت كه بهاحتمال زياد، در مرحلئ ا-1 مقطع سـهـ، از تبـهـ

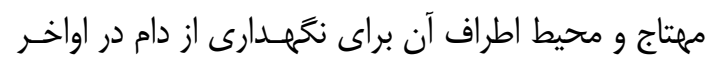

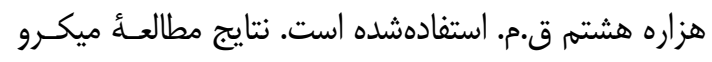

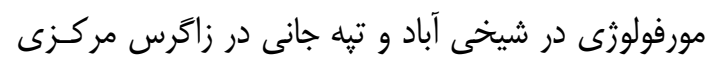

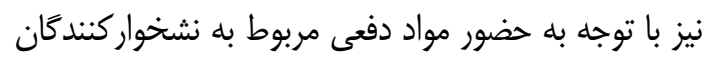

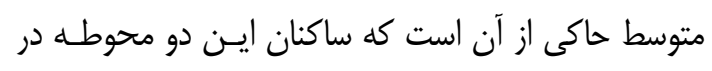

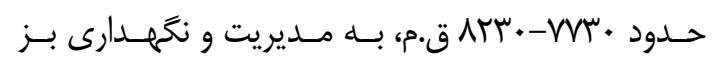

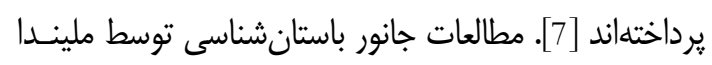

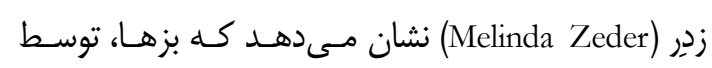

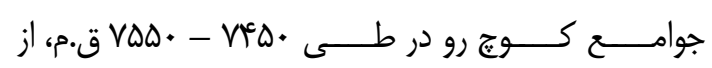

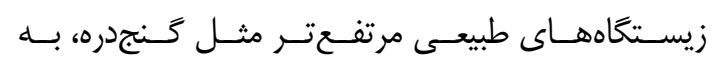

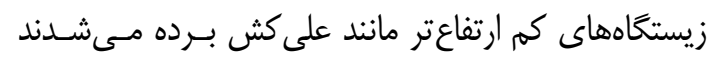

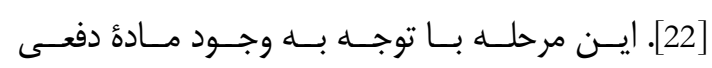

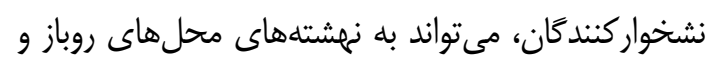

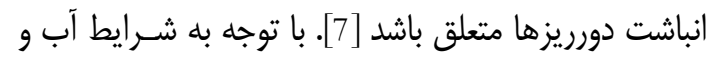

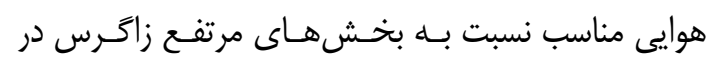

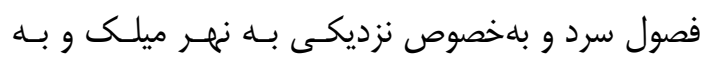

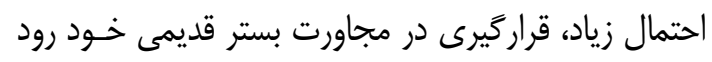
qu سال ششم، شماره اول،بهار و تابستان 9 وس
اين گَرهكها اثر كذار بوده است. افزايش گرهــــآهـن در

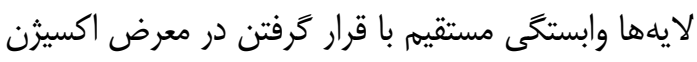

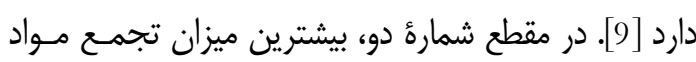

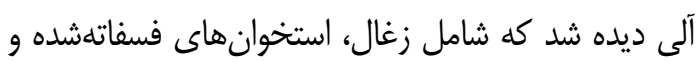

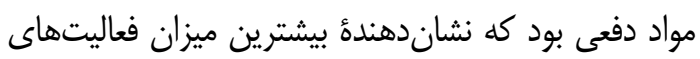
انسانى در بين هر سه مقطع بود. اين مقطع همان كَّنه كه

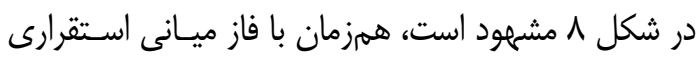

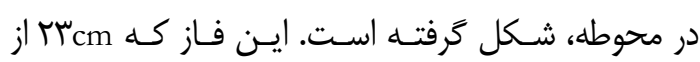

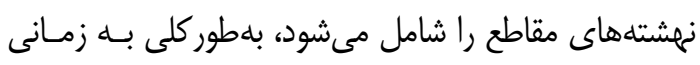
در حدود ... V. ق.م. قابل انتساب است. در وسط مقطع شماره ل، نوار تيرهرنكى قابل مشـاهده

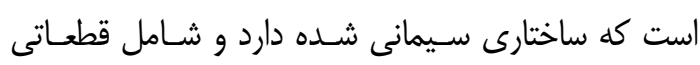

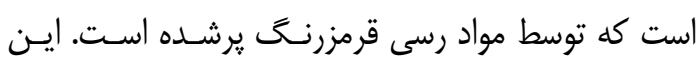

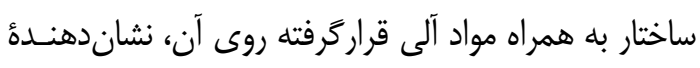
كف استقرارى است كه بر روى آن، اندود كلى وجود دارئ داردي؛

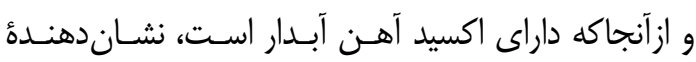

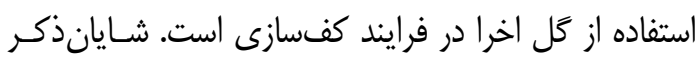

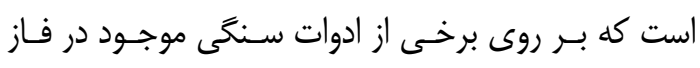

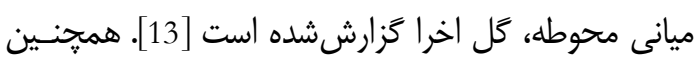

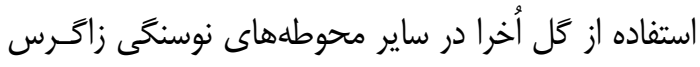

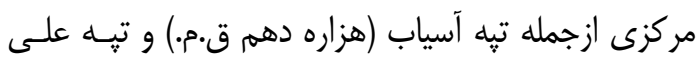

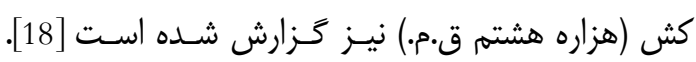
مرحلة شماره يك از مقطع شماره سـهـ، باوجوداينكـهـ آثـار

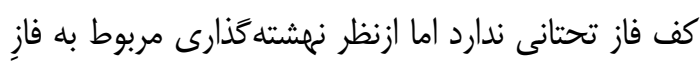

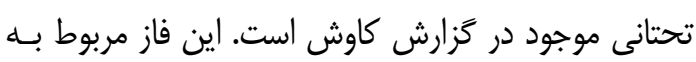

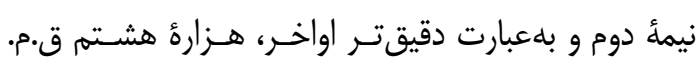

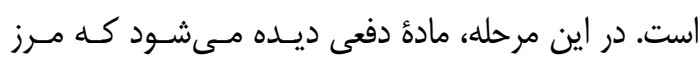

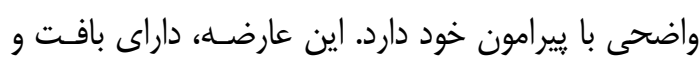

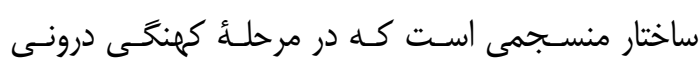

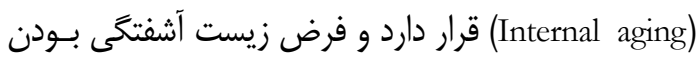

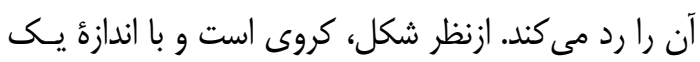

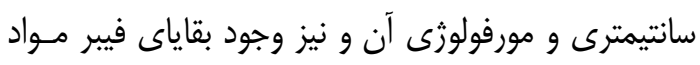

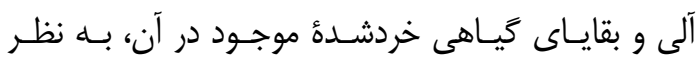
مىرسد كه مربوط به فضولات نشخوار كنندكانى با انـدازئ

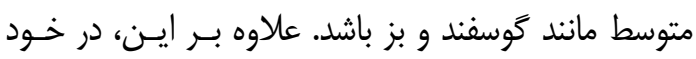

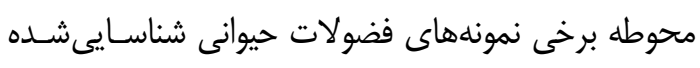

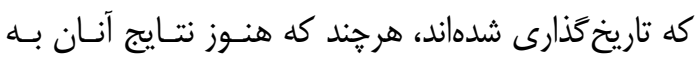


نهشتههاى طبيعى مابين آنها، همجنان ديده مىشود. در

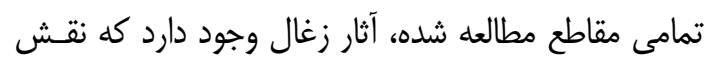

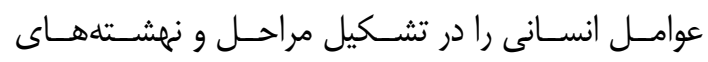

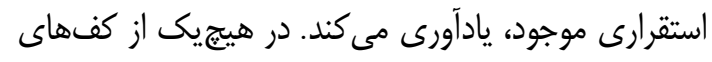

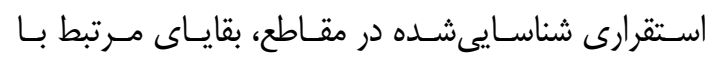

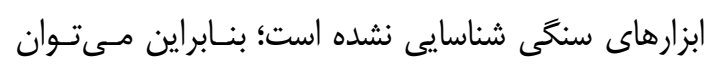

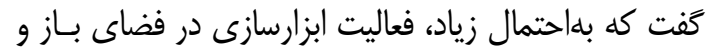

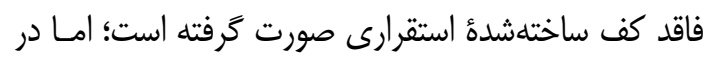
عوض، به نظر مىرسد حداقل محل برداشت نمونأه ميكرو

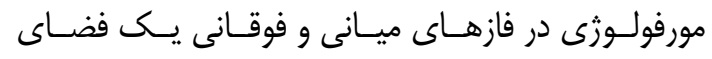

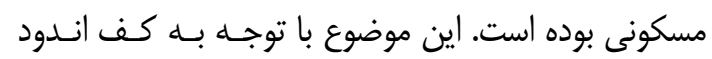

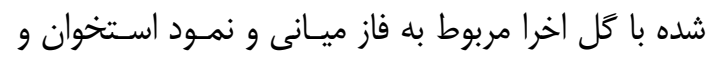

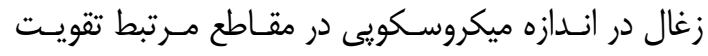

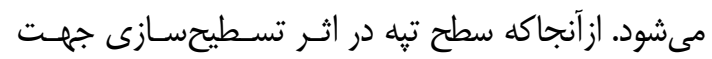

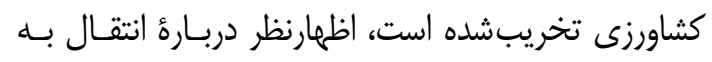

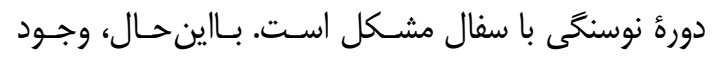

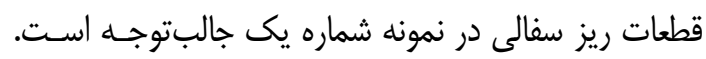

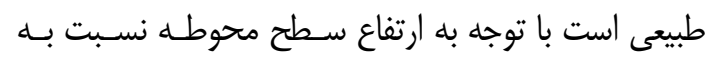

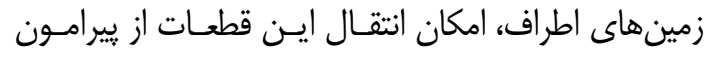

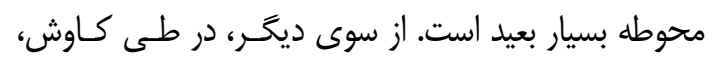

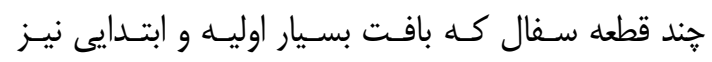

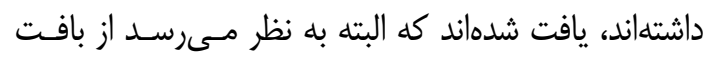

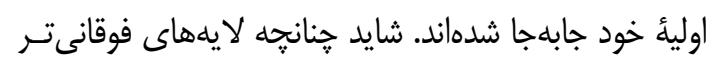

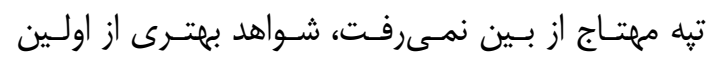

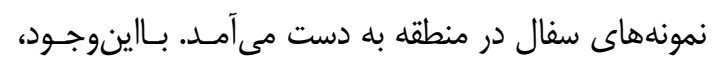

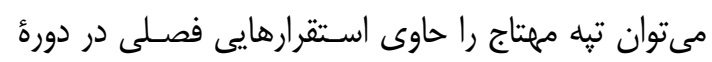

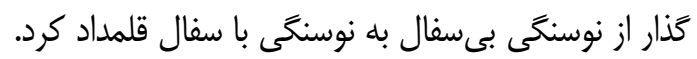

\section{سياسگز ارى}

از خانم ونـــى متيـوز (W. Matthews) و آقايـان مـارتين

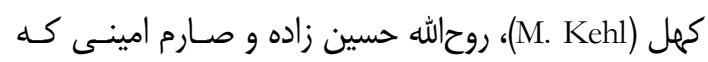

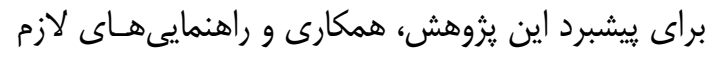

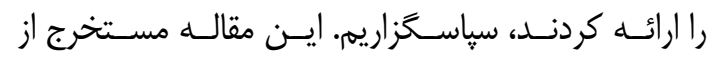

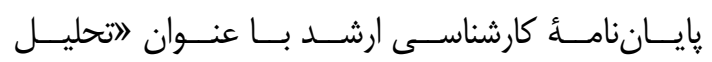

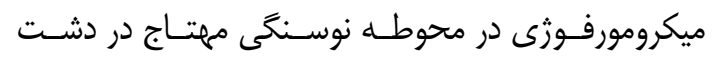

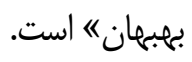

مارون، محوطه مهتاج توسـط كـوجنشـينان و داميـروران

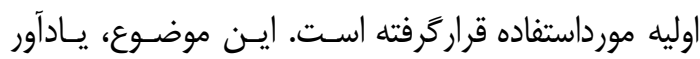

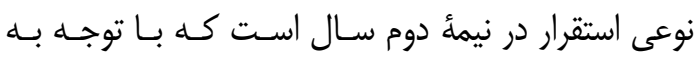
شرايط اقليمى و جغرافيايى امروزى منطقه نيز منطقى بــهـ

$$
\text { نظر مىرسد. }
$$

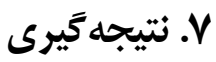

مطالعُ ميكرو مورفولوزى، به همـراه مشـاهدات در حسين

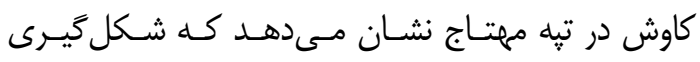

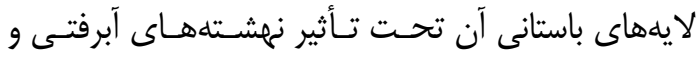

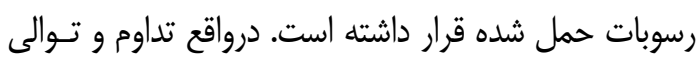
نهشته كذارى رسوبات طبيعى و فرهنكى و نيز وجـود آثـار

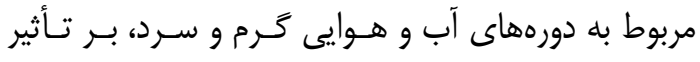

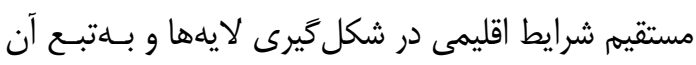
ظهور آثار مرتبط با سكونت انسان در محوطه اشـاره دارد. وجود كفهاى استقرارى و آثار زندگى روزمره ازجمله مواد

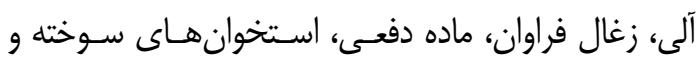

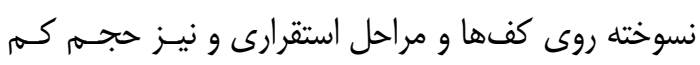

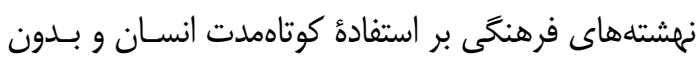

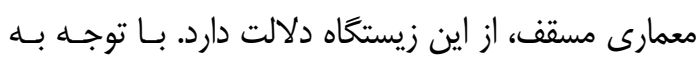

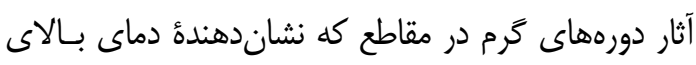

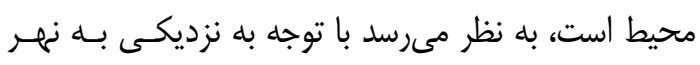

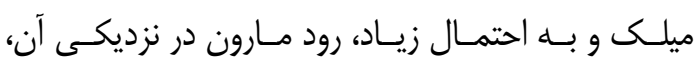

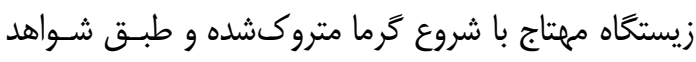

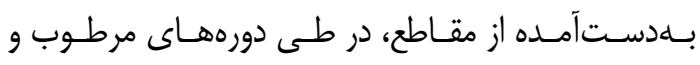

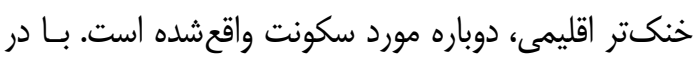

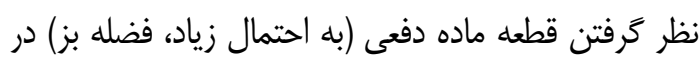

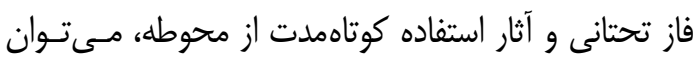

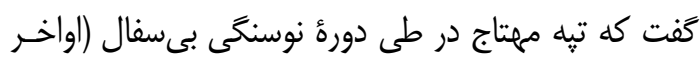

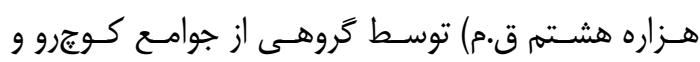

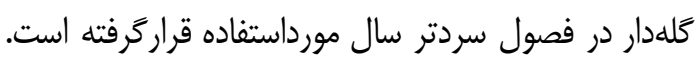

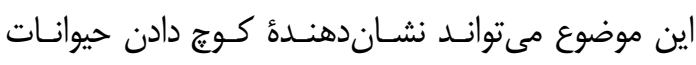

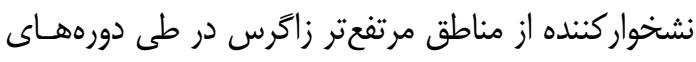

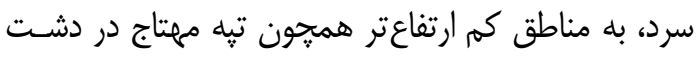

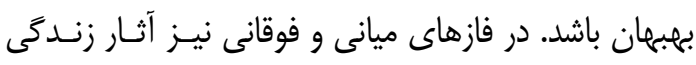

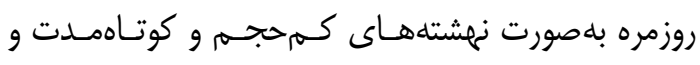

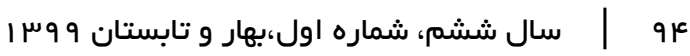




$$
\text { به طور معمول داراى يك تركيب متضاد است [6]. }
$$

\section{References}

[1] Hodder I, Orton C. Spatial Analysis in Archaeology. New Studies in Archaeology. New York \& London: Cambridge University Press; 1976.

[2] Matthews W, French C A I, Lawrence T, Cutler D F, Jones M K. Microstratigraphic Traces of Site Formation Processes and Human Activities. World Archaeology, 1997; Vol. 29, No. 2; p.281-308.

[3] Banerjea R Y, Bell M G, Matthews W, Brown, A D. Applications of micromorphology to understanding activity areas and site formation processes in experimental hut floors. Archaeological and Anthropological Sciences, 2015; 7 (1); p. 89-112.

[4] Srivastava P, Pal D K, Kalbande AR. Soil Micromorphology and its usefulness in soil survey in soil survey Manual, India: NBSS \& LUB Publication, 2009; No.146; p.1-23

[5] Goldberg P. Micromorphology in Archaeology and Prehistory. Paleorient. 1980; vol. 6; p.159-64.

[6] Stoops G. Guidelines for analysis and description of soil and regolith thinsections. Madison: Soil Science Society of America; 2003.

[7] Macphail R I, Goldberg P. Soil Micromorphology in Archaeology. Endeavour, 1990; Vol: 14, Issue: 4; p.163-71.

[8] Matthews W. Investigating Early Neolithic Materials, Ecology and Sedentism: Micromorphology and Microstratigraphy. In: Matthews R, Matthews W, Mohammadifar Y, editors. The Earliest Neolithic of Iran: 2008 Excavations at Sheikh-e Abad and Jani: Central Zagros Archaeological Project. Oxbow Books, Oxford: UK, 2013; p. 67104.

[9] Schilt F C, Heydari Guran S, Ghasidian $\mathrm{E}$, Miller $\mathrm{C}$ E, \& Conard $\mathrm{N}$ J. Micromorphological Analysis of Early
Nodule

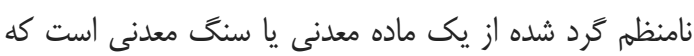

Upper Palaeolithic Cave Site of Ghare-e Boof, Iran. 52th Annual Meeting of Hugo Obermaier Gesellschaft, Leipzig; Germany, 2010.

[10] Maghsoudi M, Zamanzadeh S M, Yousefi Zoshk R. Ahmadpour H. Geoarchaeological survey of the Prehistoric sites using Micromorphology (Case study: Tapeh Maimanat abad). Archaeological Studies, 2015; 7(2); p.113-23. [In Persian]

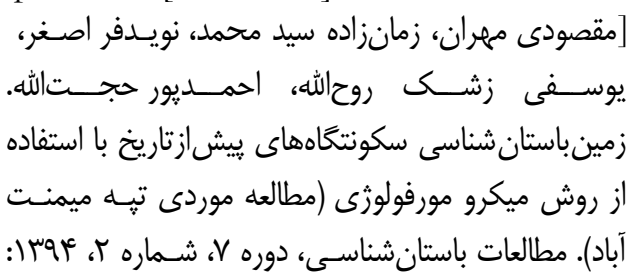

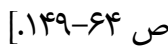

[11] Maghsoudi M, Zamanzadeh S M, Yousefi Zoshk R, Yamani M, Ahmadpour H. Geoarchaeological survey of the Chaltasian prehistoric enclosure in Jajrourd Fan, using Micromorphological techniques, 2015; 1 (2); p. 113-23. [In Persian]

] مقصودى مهران، زمان زاده سيد محمد، اهدائى افسـانه،

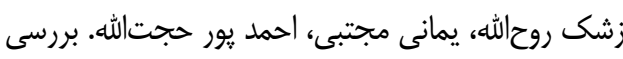

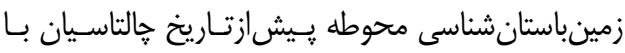

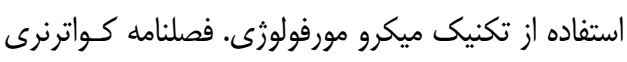

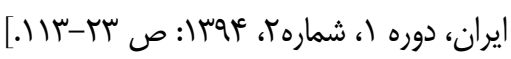

[12] Darabi H. report on the delineation and Excavation at tapeh Mahtj, Behbahan plain. Office of Cultural Heritage, Handicrafts \& Tourism of Khuzestan Province, 2016 [unpublished].

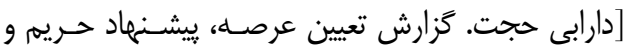

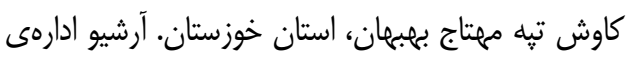

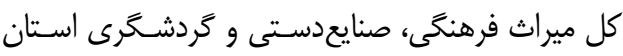
خوزستان: عوسا (كزارش منتشرنشده).

[13] Darabi H, Aghjari M, Nikzad M, Bahramiyan S. In Search of Neolithic Appearance along the Northern Shorelines of the Persian Gulf: A Report on the Excavation at the Pre-Pottery 
Neolithic Site of Tapeh Mahtaj, Behbahan Plain. International Journal of the Society of Iranian Archaeologists, 2017; vol. 3, No.5; p. 13- 22.

[14] Darabi H, Bangsgaard P, Arraz-Otaeguti A, Ahadi G, Olsen J. Investigating Early Neolithic Occupation of the lowlands in Southwestern Iran: New Evidence from Tapeh Mahtaj, Behbahan Plain, Antiquity (in press).

[15] Bullock P. Handbook for soil thin section description. Wolverhampton: Waine Research, 1985.

[16] Schaetzl R., Anderson S. Soils: Genesis and Geomorphology. New York: Cambridge University Press, 2005; p: 759.

[17] Moussavi Harami, R. Sedimentology. Mashhad: Behnashr Publishing, 2015. [In Persian]

[موسوى حرمى رضـا، رسـوبشناسـى، پـاب پـانزدهم،

انتشارات آستان قدس رضوىى: سوسبا]

[18] Darabi H, Richter T, Alibaigi S, ArrazOtaeguti A, Bangsgaard P, Khosravi SH, Yeomans L, Mortensen P. New Excavation at Tapeh Asiab, Kermanshah, Central Zagros Mountains. Archaeology, 2019; vol.2; p. 79-91.
[19] Fotuhi Dilanchi E. A Micromorphological Analysis of the Neolithic site of Mahtaj, Behbahan Plain [unpublished dissertation]. Archeology Department of Razi University, Kermanshah, 2020. [In Persian]

[فتوحى ديلانجى الهام. تحليـل ميكرومورفولـوزى (ريـز

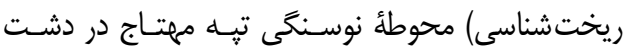

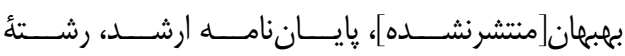

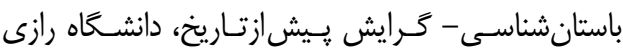

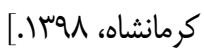

[20] Portillo M, Garsia-suarez A, Klimowicz A, Baranski M Z, Matthew W. Animal Penning and Open Area Activity at Neolithic Catalhyuk, Turkey. Journal of Anthropological Archaeology, 2019; 56, 0278-4165.

[21] Dev S. Application of micromorphology to Study Manuring Practices: A Case Study from Bronze Age in Cornwall, UK. Glob J 8Arch \& Anthropol, 2018; Vol.6, Issue.3; p.53-69.

[22] Zeder M A. A view from the Zagros: new perspectives on livestock domesticationin the Fertile Crescent. In: J-D Vigne, J Peters, and D Helmer editors, First steps of animal domestication. Oxford: Oxbow Books, 2005; 125-46. 